\title{
A biodiversity survey of scavenging amphipods in a proposed marine protected area: the Filchner area in the Weddell Sea, Antarctica
}

\author{
Charlotte Havermans $\mathbf{s}^{1,2} \cdot$ Meike Anna Seefeldt $^{2,3}\left[\right.$ Christoph Held $^{2}$
}

Received: 17 October 2017 / Revised: 23 February 2018 / Accepted: 24 February 2018

○) Springer-Verlag GmbH Germany, part of Springer Nature 2018

\begin{abstract}
An integrative inventory of the amphipod scavenging fauna (Lysianassoidea), combining morphological identifications with DNA barcoding, is provided here for the Filchner area situated in the south-eastern Weddell Sea. Over 4400 lysianassoids were investigated for species richness and relative abundances, covering 20 different stations and using different sampling devices, including the southernmost baited traps deployed so far $\left(76^{\circ} \mathrm{S}\right)$. High species richness was observed: 29 morphospecies of which 5 were new to science. Molecular species delimitation methods were carried out with 109 cytochrome c oxidase I gene (COI) sequences obtained during this study as well as sequences from specimens sampled in other Antarctic regions. These distance-based analyses (trees and the Automatic Barcode Gap Discovery method) indicated the presence of 42 lineages; for 4 species, several (cryptic) lineages were found. More than $96 \%$ of the lysianassoids collected with baited traps belonged to the species Orchomenella pinguides s. 1. The diversity of the amphipod scavenger guild in this ice-bound ecosystem of the Weddell Sea is discussed in the light of bottom-up selective forces. In this southernmost part of the Weddell Sea, harbouring spawning and nursery grounds for silverfish and icefishes, abundant fish and mammalian food falls are likely to represent the major food for scavengers. Finally, the importance of biodiversity surveys in the context of the establishment of a marine protected area in this region (Weddell Sea MPA) is highlighted and how future studies can contribute to a better understanding the ecological role of scavengers in this system is discussed.
\end{abstract}

Keywords Amphipoda $\cdot$ Lysianassoidea $\cdot$ Barcoding $\cdot$ COI gene $\cdot$ Taxonomy $\cdot$ Carrion-feeder $\cdot$ Food falls

Electronic supplementary material The online version of this article (https://doi.org/10.1007/s00300-018-2292-7) contains supplementary material, which is available to authorized users.

Charlotte Havermans and Meike Anna Seefeldt have contributed equally to this work.

$\triangle$ Charlotte Havermans

Charlotte.Havermans@awi.de

$\checkmark$ Meike Anna Seefeldt

meike.seefeldt@rub.de

1 Marine Zoology, BreMarE Bremen Marine Ecology, Universität Bremen, PO Box 330 440, 28334 Bremen, Germany

2 Alfred-Wegener-Institut Helmholtz-Zentrum für Polar- und Meeresforschung, Am Handelshafen 12, 27568 Bremerhaven, Germany

3 Department of Animal Ecology, Evolution and Biodiversity, Ruhr-Universität Bochum, Universitätsstraße 150, 44801 Bochum, Germany

\section{Introduction}

The exploitation of natural resources as well as rapid environmental changes, with their cascading consequences such as community and regime shifts, are known to have major impacts on the stability of ecosystems and thus ecosystem function (Scheffer and Carpenter 2003; Worm et al. 2006; Harley 2011; Bellard et al. 2012). The resilience of an ecosystem is dependent on its response to the loss and disturbances of critical key species and communities. The prevention of this accelerating loss of biodiversity in both coastal (e.g., Jackson et al. 2001) and open-ocean ecosystems (e.g., Worm et al. 2005), as well as ecosystem functioning and services (e.g., see Worm et al. 2006) is one of major aims of global conservation organisations like the International Union for Conservation for Nature (IUCN). One of the goals within the Aichi biodiversity targets of the convention on biological diversity (CBD), which was later reaffirmed as Goal 14 within the United Nations sustainable development 
goals (UNSDG), is to protect $10 \%$ of the worlds coastal and marine areas (CBD 2010; UNSDG 2015). The establishment of marine protected areas (MPAs) is considered a suitable tool that designates certain marine areas of specific economic, biodiversity, and species conservation interest (CBD 2004). MPAs benefit from measures preventing the exploitation of marine resources, e.g., by implementing a sustainable fishery or fishing prohibition in no-take areas as well as tourism management. While nearly every coastal country has implemented an MPAlike structure (Agardy et al. 2003), the Southern Ocean has been long time neglected in this regard despite its pristine character and large area. The Southern Ocean (sensu lato, i.e., including sub-Antarctic areas sensu De Broyer et al. 2014, hereafter SO) harbours complex ecosystems and communities which can vary over small geographical scales (Gutt et al. 2013). Its marine fauna is rich in species, particularly in the benthos, with many representatives in groups such as crustaceans, polychaetes, sponges, gastropods, and bryozoans (e.g., Arntz et al. 1994; Clarke 2008). Its unique features, e.g., geographic and climatic isolation, low and stable temperatures, and an extreme seasonality, are thought to have contributed to the evolution of a high endemicity, adaptive radiations, and species flocks observed in several taxa (reviewed in Chenuil et al. 2018).

The Antarctic treaty signatory powers, through the convention for the conservation of Antarctic marine living resources (CCAMLR), have been working on the assignment of a network of MPAs across the SO. To do so, they have agreed on a system, dividing the SO into nine marine large-scale planning domains covering convention areas in which both scientific research as well as MPAs are planned and considered (CCAMLR 2005, 2011, 2012). The South Orkney Islands Southern Shelf MPA was the first no-take area in the SO designated by CCAMLR (2009). The world's largest MPA, situated in the Ross Sea, was recently resolved in October 2016 and will be taken into force in December 2017 with $72 \%$ of its assigned area planned as a no-take area (CCAMLR 2016). Since 2011, an MPA for the East Antarctic domain is under negotiation, being proposed by Australia and the European Union (CCAMLR 2011). The European Union recently submitted a further proposal, conceptualised by Germany, requesting the Weddell Sea as a MPA covering eco-regions with characteristic biodiversity and biogeographic patterns (Teschke et al. 2016). Besides being a region of international research focus over many decades, our current knowledge of the Weddell Sea environment and the ecology of its key species are rather patchy. This particularly holds true for the southernmost eastern shelf region: the Filchner area, in which six special protection zones are proposed inside the planned MPA (Teschke et al. 2016). This area has been undersampled compared to the north-eastern Weddell Sea continental shelf (Griffiths et al. 2010), and until recently, only a handful of stations has been quantitatively sampled in the Filchner Trench (Knust and Schröder 2014).

Situated in the south-eastern Weddell Sea, the Filchner area is considered to be a key oceanographic region, characterized by a complex system of formation and mixing of water masses with various in- and outflows (Darelius et al. 2014). The Filchner Trough, intersecting the continental shelf break at $33^{\circ} \mathrm{W}$, is bounded by the Filchner-Ronne Ice Shelf, the world's largest ice shelf by volume (Fox and Cooper 1994; Grosfeld et al. 2001). In this region, strong sea-ice formation creates brine rejection and dense saline shelf water production (Haid and Timmermann 2013), whilst melting and freezing events at the base of the ice shelf are responsible for the production of ice shelf water, a precursor of the Antarctic Bottom Water (Foldvik et al. 2004). Hence, this area is of major importance for the global ocean circulation and ventilation of the world's abyss (Foldvik et al. 2004). Changes in sea-ice conditions, warming surface waters (Grosfeld and Gerdes 1998), and calving icebergs (Grosfeld et al. 2001) may have severe consequences for the Filchner-Ronne ice shelf and the production of bottom water, which are, however, difficult to predict due to the complexity of the regionally heterogeneous hydrographic conditions (Darelius et al. 2014) and the interplay between winds, eddy processes, hydrographic forcing from precipitation, sea ice, and ice shelf melting (Hellmer et al. 2017). Nevertheless, certain simulations with IPCC-simulated scenarios, based on coupled ice-ocean models, project an increase in basal melting and ice shelf thinning with a tipping point where these changes will be irreversible with strong implications on the Antarctic ice sheet (Hellmer et al. 2017).

In addition, from a faunal point of view, the Filchner area has been referred to as a hotspot, both in terms of diversity and abundance of certain taxa, mainly fish and marine mammals (Knust and Schröder 2014). In the area, the outflow of ice shelf water mixes with the oceanic deep waters of the Weddell Gyre circulation, resulting in physical fronts. This is believed to be the primary cause of this area being a biological hotspot, where upper and intermediate trophic levels are maximized (Bornemann et al. 2014). This complex regional hydrography influences the downward flux of seaice algae, phytoplankton, and derived organic matter (Auel et al. 2014). Both meso- and macro-zooplankton appear to be particularly diverse in the Filchner Trough but comparatively lower in biomass than in the more northern region of the eastern Weddell Sea (Boysen-Ennen 1987; BoysenEnnen and Piatkowski 1988; Auel et al. 2014). Conversely, nekton biomass and production have been reported to be high in the southern part of the Weddell Sea, largely due to the high abundances of the Antarctic silverfish Pleuragramma antarcticum Boulenger, 1902 (Hubold 1984), which 
are linked with high foraging occurrences of marine mammals such as Weddell seals (Plötz et al. 2001). Hence, a high number of larger carcasses of fish and mammals are expected to represent an important food source for scavenging benthic and bentho-pelagic communities.

Marine scavengers-feeding on dead organisms of plant or animal origin - are found throughout all phyla and habitats (King et al. 2007), represented by a variety of invertebrate taxa, e.g., asteroids, ophiuroids, holothurians, decapods, amphipods, and isopods but also vertebrates such as fish and seabird species (see Britton and Morton 1994 for a review). Amphipod scavengers from the superfamily Lysianassoidea are amongst the most ubiquitous and species-rich taxa in the Antarctic bentho-pelagic realm at all depths (e.g., Slattery and Oliver 1986; De Broyer et al. 2004). Despite their importance as food for higher trophic levels (fish, seabirds) and in recycling the organic carbon reaching the ocean floor, their diversity and food-web interactions are poorly studied, both globally and in the SO (Havermans and Smetacek submitted). In particular, the Filchner area, where year-round heavy sea-ice conditions severely hampered benthic diversity studies, stands in contrast with the frequently sampled north-eastern Weddell Sea (e.g., Griffiths 2010). With the exception of 4 baited trap deployments in Halley Bay $\left(74^{\circ} \mathrm{S} 27^{\circ} \mathrm{W}\right)$ during the EASIZ II cruise of R/V Polarstern in 1998 (De Broyer et al. 2004), the crustacean scavenger fauna of this region has remained virtually unstudied. Therefore, we here present an inventory of the Filchner outflow region to investigate the different amphipod species belonging to the superfamily Lysianassoidea, of which many are known to be scavengers. This has been accomplished by means of an approach combining both in-depth morphological examinations and DNA barcoding, allowing to evaluate the congruence between barcode clusters and morphospecies. With this integrative study, we aim to contribute to the biodiversity assessment of a recently proposed MPA and to deliver baseline information for subsequent monitoring studies.

\section{Materials and methods}

\section{Sampling}

Lysianassoid amphipods were collected at 20 different stations during the expedition PS82 (ANT-XXIX/9) of R/V "Polarstern" in the austral summer of 2013-2014, 18 of which are situated in the Filchner area and two stations further north near Kapp Norvegia (Fig. 1). Amphipods were collected using Agassiz and bottom trawls, rectangular midwater trawls as well as Rauschert dredge deployments. The Agassiz trawl (AGT) with an opening of 3-m width, was equipped with $10-\mathrm{mm}$ mesh in the cod end, and towed at
1 knot for 10-30 min, whereas the bottom trawl (BT) was equipped with 40-mm mesh in the cod end, and was towed at 3 knots for $30 \mathrm{~min}$. The much smaller Rauschert Dredge was deployed sideways from the ship, had an opening of $0.5 \mathrm{~m}$ width and a mesh size of $500 \mu \mathrm{m}$. It was towed at $0.5 \mathrm{knots}$ for $10 \mathrm{~min}$. Moreover, a lander equipped both with fish and amphipod traps was deployed at station 118-1 at a bottom depth of $274 \mathrm{~m}$. Three rectangular amphipod traps, equipped with a nylon gauze $(500 \mu \mathrm{m}$ mesh size $)$ and two inverse funnel-shaped openings (4 cm diameter) (see De Broyer et al. (2004) for a detailed description) and baited with large pieces of notothenioid fish from the previous sampling stations, were kept on the seafloor for 4 days. Thereafter, the lander was retrieved and thousands of crustacean specimens recovered. All amphipod specimens sampled during the PS82 expedition were fixed in pre-cooled $96-99 \%$ ethanol. Details on the sampling sites are listed in Table 1 and sampling sites represented on Fig. 1. The species record data based on this study were deposited at the World Data Center PANGAEA $^{\circledR}$ (www.pangaea.de), an open-access library, and is available with the Digital Object Identifier doi.pangaea. de/https://doi.org/10.1594/pangaea.881161.

\section{Morphological studies}

Morphospecies were sorted and counted using the stereomicroscope Leica MZ16. Morphospecies were identified based on a wide taxonomic literature including original species descriptions (Stebbing 1888; Walker 1903; Schellenberg 1926; Barnard 1932; Hurley 1963, 1965a; Andres 1986) as well as re-descriptions and revisions (Hurley 1965b; De Broyer 1985a, b; d'Udekem d'Acoz and Havermans 2012; Lowry and Kilgallen 2014a, b; Kilgallen and Lowry 2014, 2015a, b). Due to ongoing taxonomic changes and uncertainties in lysianassoid systematics, the assignment of several species to genera or families remained uncertain (referred to as inc. sed.). For this reason, some generic or specific assignments will be subjected to changes in future works; however, a taxonomical revision is by far beyond the scope of our study. Hence, we decided to use species names according to their actual taxonomic assignment in the World Amphipod Database, which updates each taxon's status according to the most recent literature (Horton et al. 2017). Museum type and non-type material was examined of the following species: [non-Uristidae] incertae sedis (inc. sed.). albinus (ZMH: K-32419), Orchomenella zschaui (Pfeffer, 1888) (K-32409), Tryphosella analogica (K.H. Barnard, 1932) (K-32415); Hippomedon kergueleni (Miers, 1875) (types; BMNH: 1876.27), Uristidae inc. sed. trigonica (Stebbing, 1888) (types; BMNH: 1889.5.15.10), Tryphosella analogica (types; BMNH: 1936.11.2.298-300), Cicadosa cicadoides (Stebbing, 1888) (types; BMNH: 1889.5.15.35), and Uristes murrayi (Walker, 1903) (types; BMNH: 

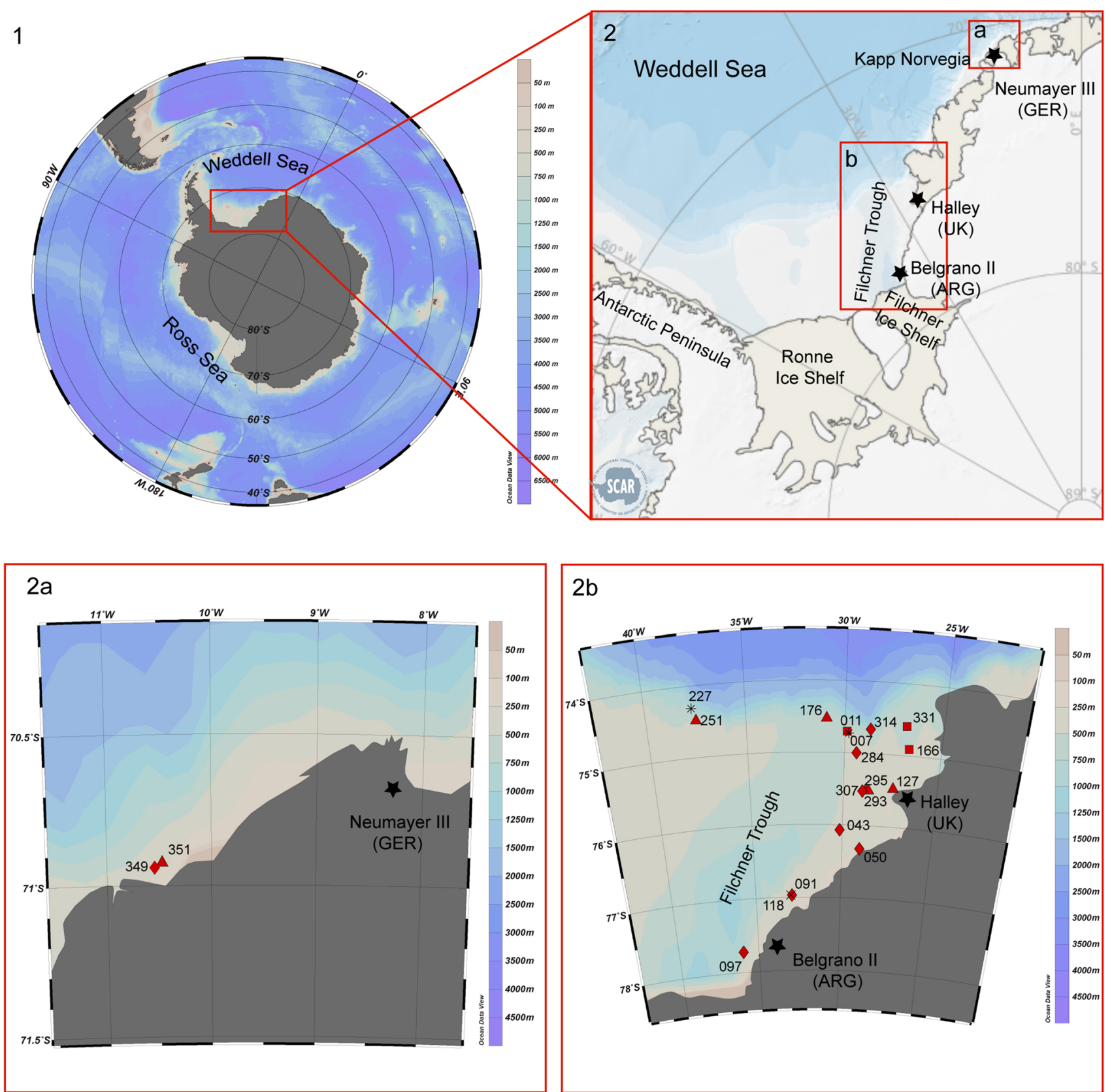

$2 b$

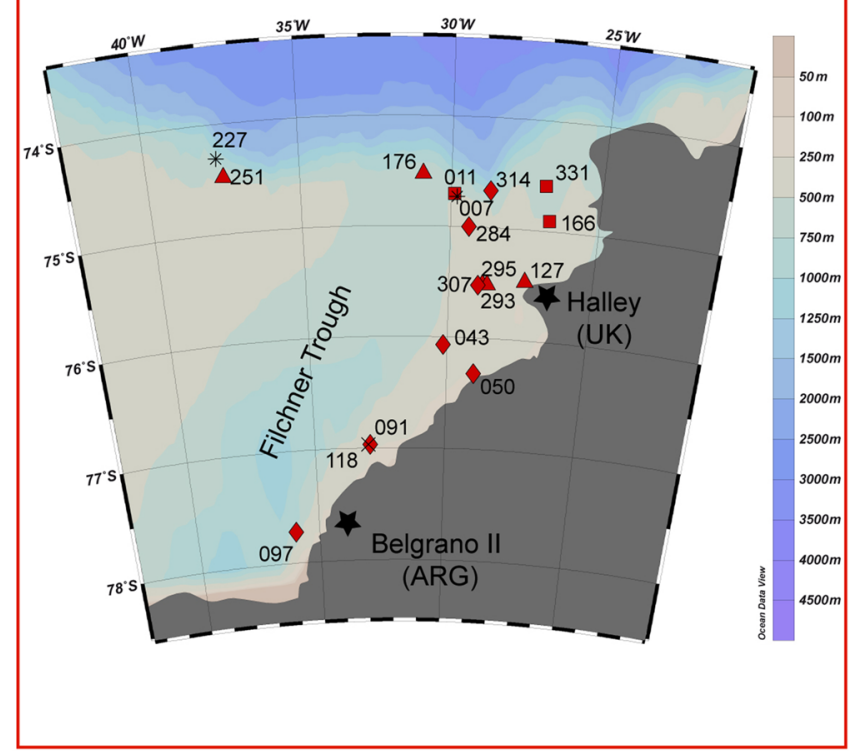

\section{Agassiz trawl \\ Bottom trawl \\ $\triangle$ Rauschert dredge}

$\times$ Baited trap

* Rectangular midwater trawl

* Scientific research station

Fig. 1 Map of the investigated area with all sampling localities examined in this study. Different symbols are used for the different gear with which the amphipods were sampled. Map information: 1, 2a, 2b: Ocean data view (Schlitzer 2015); 2: SCAR Antarctic digital database

1902.11-5-136-137). Specimens are currently stored in the Alfred Wegener Institute Helmholtz Centre for Polar and Marine Research, Bremerhaven, Germany.

\section{Molecular characterization of lysianassoid diversity}

For most of the morphospecies sampled, one or more specimens were isolated for genetic analyses (details are given in Online Resource 1). Genomic DNA was isolated from 
Table 1 Information on the 20 sampling stations and the gears used to collect lysianassoid amphipods for this study

\begin{tabular}{llllll}
\hline PS 82 station Id & Latitude & Longitude & Depth $[\mathrm{m}]$ & Date & Gear \\
\hline 007 & $74^{\circ} 43.67^{\prime} \mathrm{S}$ & $29^{\circ} 48.53^{\prime} \mathrm{W}$ & $0-399$ & 03.01 .2014 & Rectangular midwater trawl \\
011 & $74^{\circ} 42.30^{\prime} \mathrm{S}$ & $29^{\circ} 53.99^{\prime} \mathrm{W}$ & 406 & 03.01 .2014 & Bottom trawl \\
043 & $76^{\circ} 4.22^{\prime} \mathrm{S}$ & $30^{\circ} 8.70^{\prime} \mathrm{W}$ & 473 & 07.01 .2014 & Agassiz trawl \\
050 & $76^{\circ} 19.32^{\prime} \mathrm{S}$ & $29^{\circ} 0.17^{\prime} \mathrm{W}$ & 229 & 08.01 .2014 & Agassiz trawl \\
091 & $76^{\circ} 58.07^{\prime} \mathrm{S}$ & $32^{\circ} 51.48^{\prime} \mathrm{W}$ & 294 & 14.01 .2014 & Agassiz trawl \\
097 & $77^{\circ} 43.45^{\prime} \mathrm{S}$ & $35^{\circ} 58.84^{\prime} \mathrm{W}$ & 573 & 15.01 .2014 & Agassiz trawl \\
118 & $76^{\circ} 58.06^{\prime} \mathrm{S}$ & $32^{\circ} 56.17^{\prime} \mathrm{W}$ & 274 & 18.01 .2014 & Amphipod trap \\
127 & $75^{\circ} 28.78^{\prime} \mathrm{S}$ & $27^{\circ} 21.66^{\prime} \mathrm{W}$ & 276 & 19.01 .2014 & Rauschert dredge \\
166 & $74^{\circ} 54.43^{\prime} \mathrm{S}$ & $26^{\circ} 41.30^{\prime} \mathrm{W}$ & 306 & 24.01 .2014 & Bottom trawl \\
176 & $74^{\circ} 32.05^{\prime} \mathrm{S}$ & $30^{\circ} 56.50^{\prime} \mathrm{W}$ & 529 & 25.01 .2014 & Rauschert dredge \\
227 & $74^{\circ} 19,09^{\prime} \mathrm{S}$ & $37^{\circ} 40.83^{\prime} \mathrm{W}$ & $0-841$ & 31.01 .2014 & Rectangular midwater trawl \\
251 & $74^{\circ} 29.58^{\prime} \mathrm{S}$ & $37^{\circ} 29.96^{\prime} \mathrm{W}$ & 386 & 03.02 .2014 & Rauschert dredge \\
284 & $74^{\circ} 59.87^{\prime} \mathrm{S}$ & $29^{\circ} 22.90^{\prime} \mathrm{W}$ & 409 & 07.02 .2014 & Agassiz Trawl \\
293 & $75^{\circ} 31.50^{\prime} \mathrm{S}$ & $28^{\circ} 59.08^{\prime} \mathrm{W}$ & 462 & 08.02 .2014 & Agassiz trawl \\
295 & $75^{\circ} 31.34^{\prime} \mathrm{S}$ & $28^{\circ} 49.66^{\prime} \mathrm{W}$ & 421 & 08.02 .2014 & Rauschert dredge \\
307 & $75^{\circ} 31.34^{\prime} \mathrm{S}$ & $28^{\circ} 39.95^{\prime} \mathrm{W}$ & 446 & 09.02 .2014 & Rauschert dredge \\
314 & $74^{\circ} 39.93^{\prime} \mathrm{S}$ & $28^{\circ} 41.89^{\prime} \mathrm{W}$ & 712 & 10.02 .2014 & Agassiz Trawl \\
331 & $74^{\circ} 35.41^{\prime}$ & $26^{\circ} 53.21^{\prime} \mathrm{W}$ & 763 & 12.02 .2014 & Bottom Trawl \\
349 & $70^{\circ} 55.57^{\prime} \mathrm{S}$ & $10^{\circ} 28.22^{\prime} \mathrm{W}$ & 214 & 16.02 .2014 & Agassiz trawl \\
351 & $70^{\circ} 56.41^{\prime} \mathrm{S}$ & $10^{\circ} 32.58^{\prime} \mathrm{W}$ & 315 & 16.02 .2014 & Rauschert dredge \\
\hline & & & & &
\end{tabular}

112 specimens directly after the expedition in 2014 and 64 specimens in 2017. Pereopod six or one of the pleopods were used for DNA extractions that were prepared with the Nucleospin Tissue kit (Macherey-Nagel) as well as the Blood and Tissue DNeasy Kit (QIAGEN), according to the manufacturer's protocols. PCR amplifications of a fragment of the mitochondrial cytochrome oxidase subunit I gene (and hereafter COI) were carried out using the LCO1490 and HCO2198 primers (Folmer et al. 1994). The $25 \mu \mathrm{l}$ PCR reactions consisted of $0.02 \mathrm{U} / \mu \mathrm{l}$ Hotmaster Taq (5Prime $\mathrm{GmbH}$ ), $0.2 \mathrm{mM}$ dNTPs, $0.5 \mu \mathrm{M}$ of forward and reverse primers, $1 \times$ PCR-buffer, and $1 \mu \mathrm{l}$ (about $30 \mathrm{ng}$ ) of template DNA. PCR conditions were: initial denaturation at $94{ }^{\circ} \mathrm{C}$ for $2 \mathrm{~min}$, followed by 36 cycles of $94{ }^{\circ} \mathrm{C}$ for $20 \mathrm{~s}$, annealing at $42{ }^{\circ} \mathrm{C}$ for $20 \mathrm{~s}$, extension at $65^{\circ} \mathrm{C}$ for $1 \mathrm{~min}$, and a final extension at $65{ }^{\circ} \mathrm{C}$ for $15 \mathrm{~min}$. For the PCR products, both forward and reverse strands were sequenced using the sequencing services of EUROFINS (Germany). Sequences were checked for ambiguities and aligned using the software CodonCode Aligner v.3.7.1.1. (CodonCode Corporation, Deham, MA, USA). ClustalW (Thompson et al. 1994) was used as alignment algorithm. Sequence control was conducted with the basic local alignment search tool (BLAST) provided by the National Center for biotechnology information website (http://blast.ncbi.nlm.nih.gov/Blast.cgi). To prevent inclusion of pseudogenes in the analyses, electropherograms were checked for ambiguous base calls and sequences were translated into amino acids and checked for stop codons. DNA barcode data of all genetically analysed specimens (Online
Resource 1) were stored and made publically available in the project "LyAmF" (LYsianassoid AMphipods of the Filchner area) of the Barcode of Life Data System (BOLD, Ratnasingham and Hebert 2007).

First, with all COI sequences of the lysianassoid species investigated, a neighbour-joining tree was constructed with MEGA 6.06 (Tamura et al. 2013) under the Kimura2-parameter (K2P) substitution model, with 2000 bootstrap replicates and using the pairwise deletion option. In addition to the COI sequences obtained for this study, supplementary sequences of the morphospecies identified here or those of sister species from the previous studies (Havermans et al. 2011; Havermans 2012; Seefeldt et al. 2017a) were added in the alignment, to assess the intraspecific variation over a wider geographical scale or for identification purposes. Detailed information on these sequences can be found in Online Resource 1. Second, based on this data set, sequence divergences within and between the different clusters were calculated with the K2P distance model, using the pairwise deletion option in MEGA 6.06. Even though the K2P model for sequence correction has been discussed in the literature, it remains the most frequently used correction in barcoding studies (Hebert et al. 2003) and the only one allowing a comparison with genetic divergences amongst other (amphipod) taxa. Furthermore, the results of distance-based identifications do not significantly differ when using uncorrected $\mathrm{p}$ distances or K2P distances (Collins et al. 2012). Since divergences within species are in general smaller than those between species, we calculated the divergences within each 
cluster representing a morphospecies, and compared them with the interclade (or interspecific) distances observed and known from the literature. Third, the automatic barcode gap discovery (ABGD) method (Puillandre et al. 2012), also based on pairwise distance calculations, was used to independently partition the sequences into different groups or molecular operational taxonomic units (MOTUs), in a way that the distances between sequences from two distinct groups exceed a particular threshold distance (determined based on the barcode gap principle, sensu Hebert et al. 2003). As minimum intraspecific distance the default value of 0.001 , and as allowed maximum intraspecific variation ( $P \max$ ), we used 0.03 and 0.05 , based on the previous studies on COI sequences of amphipods in general (Costa et al. 2007, 2009) and lysianassoids in particular (Havermans et al. 2011; Havermans 2012).

\section{Results}

\section{Species composition}

A total of 4405 lysianassoid specimens were investigated from samples originating from 18 stations throughout the Filchner area and two stations near Kapp Norvegia (Fig. 1), collected with different gear. These specimens could be identified to 29 different morphospecies (Table 2) whilst 5 morphospecies were recognized as being new to science: Allogaussia sp. n., Tryphosella sp. n. A, Tryphosella sp. n. $\mathrm{B}$, Cheirimedon sp. n. and Hippomedon sp. n. Instead of a full description which is out of the scope of this species inventory, details on their diagnostic characters are listed in Online Resource 2. Due to a poor, insufficient condition (broken or dried out), 81 specimens could not be assigned to any morphospecies. A majority of 4230 specimens, representing $96.3 \%$ of all collected scavenging lysianassoid amphipods during this study, were sampled using the baited traps. At this station (St 118), representing the southernmost baited trap deployment carried out so far, we identified 12 morphospecies of which Orchomenella pinguides s. 1. Walker, 1903 was, with $79.41 \%$, the most dominant species collected. The other most abundant lysianassoid species were Waldeckia sp. (6.5\%; cluster B sensu Havermans 2012, hereafter designated as W. obesa morphospecies B), Abyssorchomene nodimanus (Walker, 1903) (5.65\%), and Uristes murrayi (Walker, 1903) (2.36\%). Taxonomical issues on several species identified herein are discussed below.

Despite differences between sampling methods, depth, and localities of sampling stations, influencing the observed species composition, a comparison between relative abundances and species richness at the different stations can be drawn. The highest number of morphospecies was found at station 251 using the Rauschert Dredge (14 morphospecies), followed by station 091 using the Agassiz Trawl (13), and station 118 (12), with baited traps. Stations 118 and 091 were situated in close proximity, however, consisting of a different species composition and far less specimens recovered with the trawl deployment compared to the baited traps. At station 251, on the western part of the Filchner TroLysianassoidea indet.ugh, the highest number of specimens: number of morphospecies ratio was recovered. Here, 84 specimens were sampled belonging to 14 morphospecies. Uristes murrayi morphospecies $\mathrm{B}$, corresponding to $U$. murrayi s. str. (discussed in Havermans 2012 and Seefeldt 2012), dominated the catch with 35 specimens (41.67\%). A very low specimen and species number was found for several other stations; and for many of them, single specimens only were recovered in the gear (e.g., stations $043,097,166$, 284, 293, 314, 331) (see Table 2). In all samples, only a single specimen of both Parschisturella carinata (Schellenberg, 1926) and Lepidepecreella ctenophora Schellenberg, 1926 was found at Kapp Norvegia and nowhere else. At the southernmost sampling station (097) near the ice shelf, only a single specimen was sampled, belonging to the elsewhere common and abundant species Pseudorchomene plebs (Hurley, 1965a). The morphospecies Adeliella olivieri De Broyer 1975, Hippomedon major (K.H. Barnard, 1932), [non-Uristidae] inc. sed. albinus (K.H. Barnard, 1932), and Cicadodosa cicadoides (Stebbing, 1888) are reported for the Weddell Sea for the first time. As an illustration of their full distributions hitherto acknowledged, we have presented the different species and their literature records in Online Resource 3.

\section{Morphological diversity}

We observed morphological variations between different specimens belonging to the species Orchomenella acanthurus (Schellenberg, 1931) s. 1., O. pinguides (Walker, 1903) s. 1., O. franklini (Walker, 1903) s. 1. Waldeckia obesa (Chevreux, 1905) and Uristes murrayi (Walker, 1903), all of which have been reported to consist of (pseudo)cryptic species complexes (Havermans et al. 2011; Havermans 2014). These variations occurred in both sexes and were not related to different sizes except in the case of $U$. murrayi. Here, morphological variations could not be excluded as a result of different maturity stages, since the observed variations were reported in smaller specimens. Within the species complex $O$. acanthurus, there were different character states of (1) the protrusion of epistome (moderate vs. strongly rounded, strongly projecting or not, inclining proximally or not), (2) the dorsoposterior margin of pleonite 3 (slightly vs. strongly protruding over urosomite 1), and (3) the dorsal hump on urosomite 1 (acute long hump vs. a moderate, more rounded hump) were observed. However, these morphological differences are not consistent with the genetic clades observed 


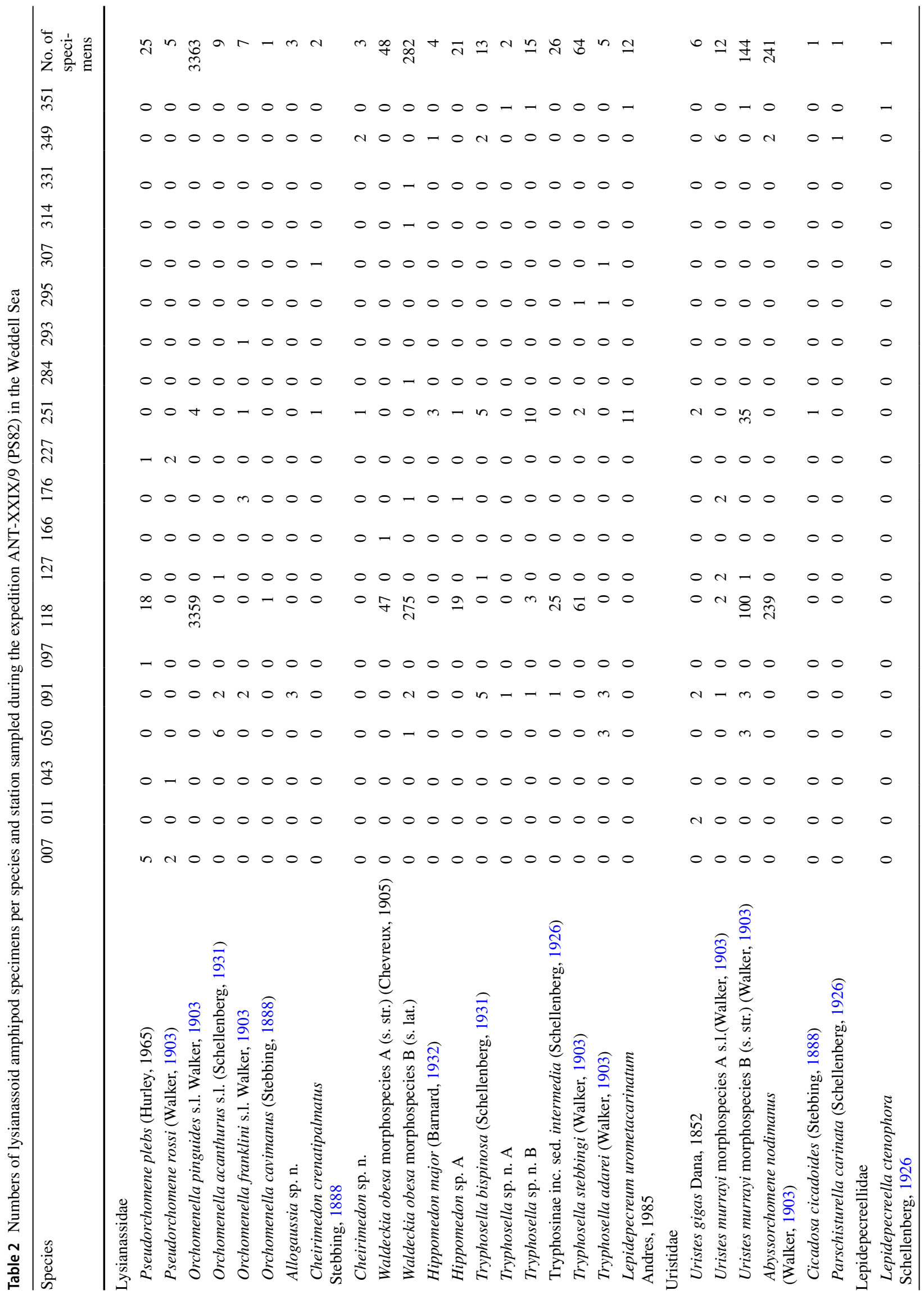


(see next section). In the $O$. pinguides complex, we could not confirm the morphological differentiation between the re-established species Orchomenella lobata (Barnard, 1932) and $O$. pinguides, as suggested by Havermans et al. (2011). One of the characters believed to be varying between the different clades is the epistome, which was observed to be proximally expanded and straight in all specimens examined for this study. A further re-examination of the type as well as the previously studied material (Havermans et al. 2011) would be needed to either confirm or reject the re-establishment of $O$. lobata, which is, however, out of the scope of this study. Moreover, sexual dimorphisms in $O$. pinguides s. 1. were observed: (1) the flagellum article 1 of antenna 1 being more elongated in males than in females, (2) the coxal plates of gnathopod 1 being distally more narrow (tapering) in females compared to males, and (3) the calceoli are present on antennae 1 and 2 in males but absent in females.

In $O$. franklini s. 1., several variations in character states were detected for the urosomite 1, the telson, the epistome, and the first antenna. In both Walkers original description (1903) as well as in the re-description of Hurley (1965b), the urosomite 1 is described as being "without carina or depression" or "without keel", respectively. The specimens investigated for this study, however, revealed either no depression ( $\widehat{\jmath}$, PS82OspC77) or a depression and weak carina ( + , PS82OspC74), suggesting that this character may be sexually dimorphic. While in the original species description (Walker 1903), the telson is described as "divided to about one-third of its length", we have observed intermediate states in our analysed specimens with a telson cleft at less than one-third, to a widely notched up to one-third cleft telson. These subtle differences were observed between two specimens belonging to the same genetic cluster ( 0 , PS82OspC77; ㅇ, PS82OspC74) as well as between these and specimens from the Filchner area recovered in another cluster (see next section and Fig. 2). In addition, the proximal angle of the epistome varies in some degrees. The same holds true for the first article of the flagellum of antenna 1 which can be more elongated in some specimens compared to the descriptions of Walker (1903) and Hurley (1965b) that are less or not elongated at all. In total, the characters of the $O$. franklini $i$. 1. specimens are too inconsistent between gender and clusters to be considered as adequate characters for species or cluster delimitations.

For the two morphospecies of Waldeckia, morphological differences have already been detected and described in the previous studies (Havermans 2012; Seefeldt et al. 2017a) and the re-description of $W$. obesa s. str. (corresponding to morphospecies A) as well as the description of the new Waldeckia species (morphospecies B) is in the process of publication (d'Udekem d'Acoz, pers. comm.). Similarly, morphological differences are consistent with the genetic clade in the $U$. murrayi complex, in which morphospecies 
Fig. 2 Neighbour-joining tree based on $\mathrm{K} 2 \mathrm{P}$ distances inferred from the COI sequences of lysianassoid amphipods investigated in this study (names indicated in bold) as well as supplementary sequences from Havermans et al. (2011), Havermans $(2012,2014)$ and Seefeldt et al. (2017). Bootstrap values (Nreps $=2000)$ higher than $70 \%$ are shown. For clarity, large clusters representing the morphospecies Pseudorchomene plebs, P. rossi, Orchomenella pinguides, O. acanthurus, and Uristes murrayi morphospecies A and B have been collapsed and the number of specimens belonging to the clusters added between brackets. Morphospecies identified in this and other studies are identified by light grey vertical bars. The dark grey vertical bars next to the different morphospecies represent species delimitations based on the results of the ABGD analyses. For the ABGD analysis based on a maximum intraspecific variation $(P \max )$ of 0.03 and of 0.05 , the same 42 clusters were recovered. Note that this tree is based on distances and does not represent the phylogenetic relationships between the species but only supports species clustering and delimitation. Geographic localities are added after each specimen code for the non-collapsed clusters. Abbreviations: FOS Filchner outflow system, $S E$ south-eastern part, $W$ western part, $E$ eastern part, $K N$ Kapp Norvegia, HVIIS Haakon VII Sea, KGI King George Island, EI Elephant Island, $A P$ Antarctic Peninsula region, SS Scotia Sea

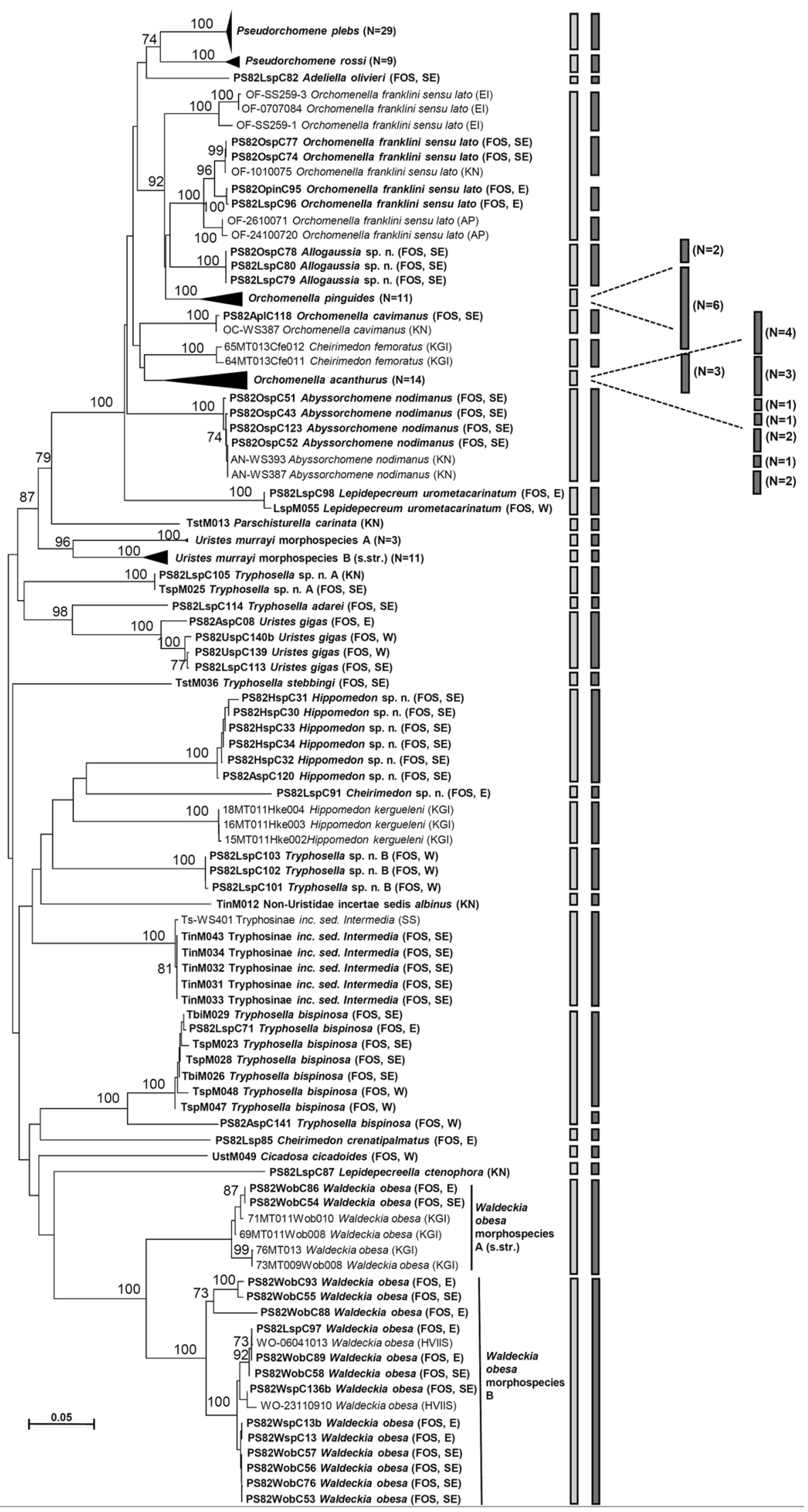


B corresponds to $U$. murrayi s. str., whilst morphospecies A is yet undescribed, but reported in Seefeldt (2012) and Havermans (2012). Morphological characteristics of the yet to be described new species are given in Online Resource 2. Nonetheless, a full description of these species is out of the scope of this paper and will be published elsewhere, together with detailed molecular analyses.

\section{DNA barcode data and analyses}

From the 176 DNA extracts from amphipods collected during the expedition PS82, 109 successful PCRs were carried out for the barcode region of the COI gene, corresponding to an average of ca. $60 \%$ success rate. This was much lower (ca. 30\%) for the PCRs accomplished on the DNA extracts isolated in 2017, most likely due to the degradation of DNA over time. The complete COI dataset of lysianassoid specimens used for analyses consisted of 165 sequences. Besides the 109 sequences generated for this study, 56 sequences were added from the previous studies for the species Pseudorchomene plebs, P. rossi, Orchomenella franklini, $O$. pinguides, $O$. acanthurus, O. cavimanus, Abyssorchomene nodimanus, Uristes murrayi, Hippomedon kergueleni (Miers, 1875), Tryphosinae inc. sed. intermedia, Cheirimedon femoratus (Pfeffer, 1888), and Waldeckia obesa. First-time DNA barcode data were established and added to the BOLD System library for Adeliella olivieri, [nonUristidae] inc. sed. albinus, Lepidepecreum urometacarinatum, Tryphosella bispinosa, Cheirimedon crenatipalmatus, Cicadosa cicadoides, Lepidepecreella ctenophora, and five new, yet undescribed lysianassoid species. Details on the newly obtained sequences as well as sequences from previous studies can be found in Online Resource 1. The alignment consisted of 657 bases, 322 of which were conserved and 335 variables, with 315 parsimony-informative sites. Translation revealed a higher mutation rate at third codon positions as well as the absence of stop codons, typical for a functional protein-coding gene as opposed to a pseudogene.

The results of the neighbour-joining analysis (Figs. 2, 3, 4) show that most morphospecies of which multiple specimens were sampled have been recovered as monophyletic clusters that were well supported by bootstrap values exceeding 95\%. In addition, the morphospecies of which only one specimen was sampled were shown as distinct lineages of which the elevated branch lengths and high divergences clearly supported their distinct species status. This also was true for the morphospecies corresponding to undescribed species Allogaussia sp. n., Tryphosella sp. n. A, Tryphosella sp. n. B, Cheirimedon sp. n., and Hippomedon sp. n. The tree also confirmed the previously documented existence of distinct genetic lineages within the species $O$. pinguides, $O$. franklini, O. acanthurus, $U$. murrayi, and W. obesa. The ABGD analyses recovered 42 clusters or molecular operational taxonomic units (MOTUs) for both priors (Pmax $=0.03$ and 0.05 ), and the (in) congruence of both molecular and morphological species delimitation was indicated on the trees shown in Figs. 2 and 3. The morphospecies $O$. franklini s. 1. consisted of minimum four clades consisting of sequences from the Filchner area, as well as sequences from previous studies, all supported by high bootstrap values and with an intraclade variation (see Table 3 ) considerably exceeding values commonly used for amphipod species delimitation (3-5\%, also used as thresholds in the ABGD analyses). In $O$. pinguides s. 1., 3 clusters were recovered with the ABGD analyses and well supported by high bootstrap values (100\%) in the Neighbour-Joining Tree (Figs. 2 and 4). The same was true for $O$. acanthurus, consisting of seven well-supported species-level lineages according to the ABGD analyses (see Figs. 2 and 4), of which several were singletons. Specimens from the different clusters were separated by a mean intraclade variation of $10 \%$ (Table 3 ), which clearly exceeds the threshold of interspecific divergences commonly observed in amphipods. Finally, in Tryphosella bispinosa, two lineages were observed, one cluster of 7 sequences and one divergent sequence, of which the specimen was, however, identified as belonging to the same morphospecies.

\section{Genetic structure of lysianassoid species in the Weddell Sea and across the Southern Ocean}

Within several species, a high genetic homogeneity was observed across a wide geographic range, based on low genetic divergences observed between sequences from specimens sampled in the Filchner area and those from other localities across the Southern Ocean (Havermans et al. 2011; Havermans 2012). A mean intraspecific variation of $0.3 \%$ for K2P was observed in the case of Pseudorchomene plebs, for which half of the haplotypes were shared between all specimens sequenced (see Table 3). Across the Filchner area, genetic diversity was particularly low, since only three distinct haplotypes were found for the 14 specimens sequenced. A low genetic diversity was observed between specimens from localities comprising the Scotia Sea, several areas in the Peninsula region, Elephant Island, Bouvet Island, Kapp Norvegia, and the Filchner area (see Fig. 3), and across a depth ranging from 270 to $2889 \mathrm{~m}$. Moreover, several individuals from this study were sampled by means of a rectangular midwater trawl (station 007). This indicates their occurrence in the pelagic environment, where they have been sampled between $500 \mathrm{~m}$ and the surface, as found in the previous studies (De Broyer et al. 2007; d'Udekem d'Acoz and Havermans 2012). For P. rossi, a mean genetic diversity of $0.9 \%$ was observed between specimens from the Peninsula, Kapp Norvegia, and the western and eastern side of the 
Fig. 3 Details of the concatenated clusters in Fig. 2 of Pseudorchomene plebs and $P$. rossi, Bootstrap values (Nreps $=2000$ ) higher than $70 \%$ are shown. For both Pseudorchomene species, a genetic homogeneity was observed across all sequences from this and other studies (Havermans et al. 2011; Havermans 2012) and the localities where the specimens originated from are indicated next to the names. Specimens sequenced for this study are indicated in bold

\author{
AP-G10 P. plebs - Elephant Island, $334 \mathrm{~m}$ \\ AP-31100710 P. plebs - Kapp Norvegia, $550 \mathrm{~m}$ \\ AP-2419173 P. plebs - Bouvet Island, $515 \mathrm{~m}$ \\ AP-SS270 P. plebs - Scotia Sea, $270 \mathrm{~m}$ \\ AP-0810072 P. plebs - Scotia Sea, $349 \mathrm{~m}$ \\ AP-2609072 P. plebs - Scotia Sea, 349 m \\ AP-LB383 P. plebs - Larsen B, Antarctic Peninsula, $383 \mathrm{~m}$ \\ PS82AspC07 P. plebs - St.007 E Filchner area, 0 - $399 \mathrm{~m}$ \\ PS82AspC04 P. plebs - St.007 E Filchner area, 0 - $399 \mathrm{~m}$ \\ PS82AspC02 P. plebs - St.007 E Filchner area, 0 - $399 \mathrm{~m}$ \\ PS82PspC134 P. plebs - St.097 SE Filchner area, $573 \mathrm{~m}$ \\ PS82UspC25 $P$. plebs - St.118 SE Filchner area, $274 \mathrm{~m}$ \\ PS82ProC135 P. plebs - St.007 E Filchner area, 0 - $399 \mathrm{~m}$ \\ PS82UspC24 $P$. plebs - St.118 SE Filchner area, $274 \mathrm{~m}$ \\ AP-J12 P. plebs - Scotia Sea, $822 \mathrm{~m}$ \\ AP-2109078 P. plebs - Bouvet Island, $515 \mathrm{~m}$ \\ AP-0506081 P. plebs - Bouvet Island, $515 \mathrm{~m}$ \\ AP-A1 P. plebs - Antarctic Peninsula, depth unkown \\ AP-0304076 P. plebs - Scotia Sea, $1943 \mathrm{~m}$ \\ AP-SS1943 P. plebs - Scotia Sea, $1943 \mathrm{~m}$ \\ PS82UspC28 $P$. plebs - St.118 SE Filchner area, $274 \mathrm{~m}$ \\ PS82UspC26 $P$. plebs - St.118 SE Filchner area, $274 \mathrm{~m}$ \\ PS82WspC27 P. plebs - St.118 SE Filchner area, $274 \mathrm{~m}$ \\ AP-1110076 P. plebs - Scotia Sea, $2889 \mathrm{~m}$ \\ - AP-0510071 P. plebs - Bouvet Island, $515 \mathrm{~m}$ \\ 100 \\ AP-08100719 P. plebs - Scotia Sea, $270 \mathrm{~m}$ \\ PS82PrC110 P. plebs - St.227 W Filchner area, 0 - $841 \mathrm{~m}$ \\ 96 \\ PS82AspC05 P. plebs - St.007 E Filchner area, 0 - $399 \mathrm{~m}$ \\ AP-08100722 P. plebs - Scotia Sea, $270 \mathrm{~m}$ \\ AR-I19 P. rossi - Antarctic Peninsula, $383 \mathrm{~m}$

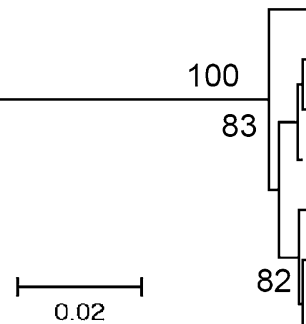 \\ PS82PpIC112 P. rossi - St.227 W Filchner area, 0 - $841 \mathrm{~m}$ \\ AR-1010076 P. rossi-Kapp Norvegia, $847 \mathrm{~m}$ \\ PS82PpIC111 P. rossi - St.227 W Filchner area, $0-841 \mathrm{~m}$ \\ PS82PpIC137 P. rossi - St.166 E Filchner area, $306 \mathrm{~m}$ \\ AR-3110078 P. rossi-Kapp Norvegia, 550 m \\ PS82AspC06 P. rossi - St.007 E Filchner area, 0 - $399 \mathrm{~m}$ \\ PS82PpIC138 P. rossi - St.166 E Filchner area, $306 \mathrm{~m}$ \\ PS82AspC03 P. rossi - St.007 E Filchner area, 0 - $399 \mathrm{~m}$
}

Filchner Trough (Fig. 3); however, the haplotypic diversity was higher with each sequence obtained representing a different haplotype (Table 3). Similarly, specimens of Abyssorchomene nodimanus were also characterized by low genetic divergences between localities in the Filchner area and the Weddell Sea (Kapp Norvegia) (for localities of the specimens, we refer to Online Resource 1).
The sequences belonging to specimens of $O$. franklini sampled for this study were found in two distinct lineages (Fig. 2), of which one consisted only of new sequences from specimens sampled in the eastern part of the Filchner area, whilst the other cluster consisted of sequences from specimens from the south-eastern Filchner area, together with a sequence (OF-1010075) belonging to a specimen sampled 
Fig. 4 Details of the concatenated clusters in Fig. 2 of the species complexes Orchomenella pinguides, $O$. acanthurus and the two morphospecies A and $\mathrm{B}$ found within $U$. murrayi with sequences from this and other studies (Havermans et al. 2011; Havermans 2012). Bootstrap values $($ Nreps $=2000)$ higher than $70 \%$ are shown. The localities where the specimens originated from are indicated next to the names. Results from the ABGD analyses (same clusters were recovered for $P \max =$ 0.03 and 0.05 ) are added next to the clusters, and the sampling localities specified. Specimens sequenced for this study are indicated in bold
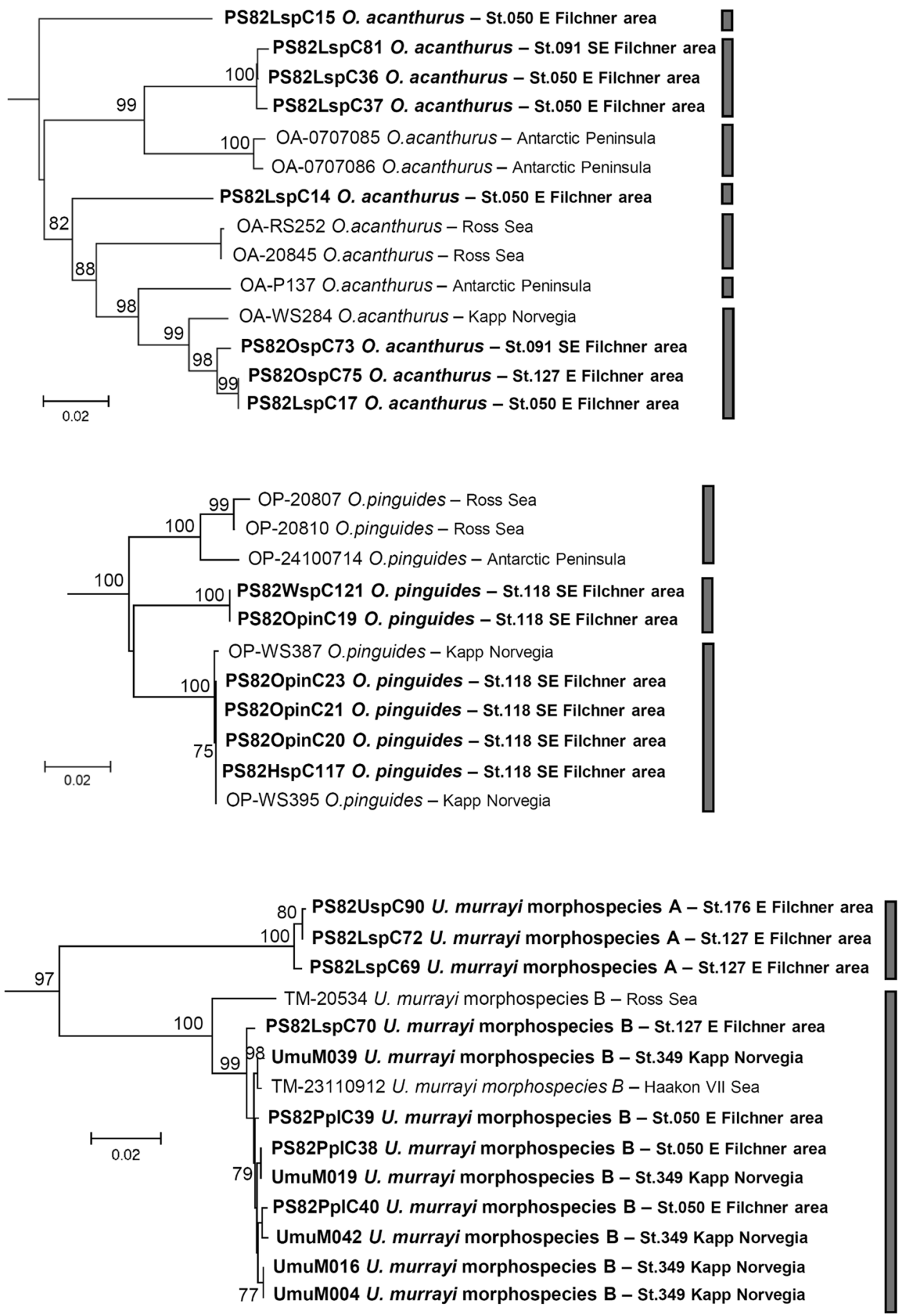

at Kapp Norvegia. Whether the lineage represented only by Filchner samples is endemic to the region or more widespread needs to be tested with further genetic analyses on additional samples. In addition, for $O$. pinguides s. 1., two lineages were found to occur in the Filchner area. For $T$. bispinosa, a divergent lineage representing a single sequence was found to occur in sympatry at station 251 (separated by distances $1-2 \mathrm{~km}$ ) with the cluster consisting of other specimens originating from several localities throughout the
Filchner area (south-eastern, eastern, and western sides of the Filchner Trough). Both morphospecies A and B of $U$. murrayi are present in the samples investigated here, and both were recovered at station 127 . For morphospecies B, low genetic divergences were observed between specimens sampled in the Ross Sea, the Haakon VII Sea, Kapp Norvegia, and the Filchner area (Fig. 4). T. inc. sed. intermedia showed a genetic homogeneity between specimens from the Filchner area and one sampled in the Scotia Sea. Finally, 
Table 3 Mean intraspecific variation within the identified morphospecies calculated using the Kimura 2-parameter $(\mathrm{K} 2 \mathrm{P})$ as well as the number of individuals per species and haplotypes within the species for the whole Southern Ocean and the Filchner area in particular. Species of which only a single specimen was sequenced are not listed. In bold are indicated the morphospecies of which the intraspecific variation exceeds the thresholds of 0.03 or 0.05

\begin{tabular}{|c|c|c|c|c|c|}
\hline Morphospecies & No. ind. & $\begin{array}{l}\text { No. hap- } \\
\text { lotypes }\end{array}$ & No. ind PS82 & $\begin{array}{l}\text { No. hap- } \\
\text { lotypes } \\
\text { PS82 }\end{array}$ & $\mathrm{K} 2 \mathrm{P}$ \\
\hline Pseudorchomene plebs & 28 & 13 & 14 & 3 & 0.003 \\
\hline Pseudorchomene rossi & 9 & 9 & 6 & 6 & 0.009 \\
\hline Orchomenella franklini & 10 & 9 & 4 & 3 & 0.054 \\
\hline Allogaussia sp. n. & 3 & 1 & 3 & 1 & 0.000 \\
\hline Orchomenella pinguides & 11 & 6 & 6 & 2 & 0.043 \\
\hline Orchomenella cavimanus & 2 & 2 & 1 & 1 & 0.000 \\
\hline Cheirimedon femoratus & 2 & 2 & 0 & 0 & 0.009 \\
\hline Orchomenella acanthurus & 14 & 13 & 7 & 7 & 0.100 \\
\hline Abyssorchomene nodimanus & 6 & 4 & 4 & 4 & 0.002 \\
\hline Lepidepecreum urometacarinatum & 2 & 1 & 2 & 1 & 0.000 \\
\hline Uristes murrayi morphospecies A & 3 & 3 & 3 & 3 & 0.003 \\
\hline Uristes murrayi morphospecies B & 11 & 8 & 4 & 7 & 0.010 \\
\hline Uristes gigas & 4 & 4 & 4 & 4 & 0.022 \\
\hline Hippomedon sp. n. & 6 & 4 & 6 & 4 & 0.002 \\
\hline Hippomedon kergueleni & 3 & 3 & 0 & 0 & 0.001 \\
\hline Tryphosella sp. n. A & 2 & 1 & 2 & 1 & 0.000 \\
\hline Tryphosella sp. n. B & 3 & 2 & 3 & 2 & 0.001 \\
\hline Tryphosinae incertae sedis intermedia & 6 & 3 & 5 & 2 & 0.000 \\
\hline Tryphosella bispinosa & 8 & 8 & 8 & 8 & $\mathbf{0 . 0 3 1}$ \\
\hline Waldeckia obesa morphospecies A (s. str.) & 6 & 5 & 2 & 1 & 0.014 \\
\hline Waldeckia obesa morphospecies B & 15 & 12 & 13 & 10 & 0.028 \\
\hline
\end{tabular}

both morphospecies of $W$. obesa were found to occur at the same sampling station (the trap deployment, station 118), and morphospecies $\mathrm{B}$ showed low genetic divergences between specimens found in the southern and eastern parts of the Filchner outflow system and in the Haakon VII Sea.

\section{Discussion}

\section{An integrative method for biodiversity studies: congruence between barcodes and morphology}

From the previous integrative studies on amphipods using the barcoding gene ( Radulovici et al. 2009; Havermans et al. 2011, 2013; Seefeldt et al. 2017a; Jażdżewska et al. 2018), the use of thresholds for species delimitation analyses appeared to be straightforward, since, in most cases, the average intraspecific variation was an order of magnitude smaller than the observed average interspecific divergence, and in many instances, a barcode gap could be detected (Havermans et al. 2011; Seefeldt et al. 2017a). In this study, the ABGD method using a threshold based on the level of divergence previously established for lysianassoids (Havermans et al. 2011; Havermans 2012), revealed 42 clusters, which did not correspond to the 30 morphospecies isolated for the molecular analysis. The main incongruences between the molecular and morphological species delimitation were caused by the presence of species complexes, of which all but one (T. bispinosa) were already detected in the previous studies ( $O$. acanthurus, $O$. pinguides and $O$. franklini, see Havermans et al. 2011). For both W. obesa and U. murrayi, two recognized morphospecies are currently being described elsewhere. In the cases of the species complexes $O$. pinguides, $O$. franklini, and $O$. acanthurus, no significant or consistent morphological differences could be found after a detailed examination of the specimens belonging to the different genetic clusters observed, and hence, we argue that these represent cases of cryptic speciation. This is corroborated by the fact that most of the lineages detected occurred in relative sympatry (i.e., separated by a maximum distance of 1-2 km, depending on the distance covered by the trawl or dredge). As an example, specimens belonging to the four different lineages of $O$. acanthurus present in the Filchner area were sampled at station 050 .

\section{Taxonomic problems and cryptic species as an impediment for biodiversity studies?}

Lysianassoid systematics has been a subject of discussions and taxonomic re-organizations for more than a century (e.g., Hurley 1963; De Broyer 1985a; Lowry and Stoddart 1993, 1995, 1997, 2011; Lowry and Kilgallen 2014a, b, 
2015a, b; Kilgallen and Lowry 2015a, b); however, several taxonomic issues remain unsolved, whilst others have been dealt with or are newly arising (discussed in Havermans 2012). Some taxa, in particular within the genera Tryphosella and Uristes, are currently in an uncertain taxonomic placement, mainly due to the incompleteness of some recent taxonomic revisions (Lowry and Stoddart 2011; Lowry and Kilgallen 2014a), based on morphological analyses only and without an adequate re-organization of the taxa a posteriori. The major challenge in lysianassoid taxonomy is the frequent use of diagnostic characters that are often the result of convergent evolution (e.g., Havermans et al. 2010) or that correspond to intraspecific variation (e.g., sexual dimorphism), as illustrated by the case of $O$. acanthurus in this study. The application of DNA barcoding has revealed an increasing number of cases where morphospecies were found to represent (pseudo)cryptic species complexes. Furthermore, within the synthesized taxon "orchomenids", incongruence between molecular and morphological results has often been encountered. As an example, morphological differences within Orchomenella can be very minor for genetically distinct lineages, which were the case for $O$. lobata, $O$. kryptopinguides, and $O$. pinguides, as discussed in Havermans et al. (2011). On the contrary, morphological differences can be striking and consistent, while the genetic divergences observed were quite low compared with the usual interspecific variation observed between other, welldefined, lysianassoid species. This is the case for O. rotundifrons vs. O. denticulata (Seefeldt et al. 2017a), and Pseudorchomene coatsi and P. lophorachis (d'Udekem d'Acoz and Havermans 2012). Hence, for this group, it is necessary to apply an integrative approach combining DNA and morphology, to carry out an effective biodiversity survey. Disentangling the systematics of "orchomenids" and other lysianassoid taxa urges a major comprehensive revision based on mitochondrial and nuclear genes, and a thorough comparison between molecular and morphological results to pinpoint suitable diagnostic characters for the different taxa.

The diversity and ecological niches of lysianassoid scavengers in general, and the importance of morphologically similar sister species (including cryptic species) in particular need to be clarified to evaluate species-specific functional role and significance for ecosystem functioning. It has been demonstrated that a higher biodiversity is commonly associated with a higher biomass production in natural ecosystems (Duffy et al. 2017) and that it also influences their resilience towards changes (e.g., disturbances caused by climate change or exploitation of natural resources). Indeed, even relatively small ecological units such as species and communities can influence the resilience of an ecosystem when it comes to community shifts or loss of species (Mori et al. 2013; Nimmo et al. 2015; Mori 2016). Whether species complexes within scavenging amphipods have evolved different feeding strategies and life-history traits or whether they share the same (micro)habitats, needs to be determined to have a better understanding of their ecological roles and their significance for monitoring and conservation efforts. A recent study on subterranean amphipods has shown that morphologically cryptic species in fact occupied very distinct feeding niches ranging from predation to filter-feeding (Fišer et al. 2015). Furthermore, also within the scavenging guild, distinct succession patterns linked to feeding strategies (carcass "openers" vs. "squeezers") and morphological adaptations to opportunistic or obligate carrion-feeding, may allow niche partitioning amongst closely related lysianassoids (Seefeldt et al. 2017b). In this context, in-depth morphological investigations based on scanning electron microscopy of the feeding apparatus (e.g., a mouthpart-atlas, Arndt et al. 2005), as well as feeding experiments characterizing feeding rates and preferences (Seefeldt et al. 2017b), can elucidate subtly different feeding methods within the scavenging guild.

\section{Lysianassoid species richness, distributions, and connectivity}

Compared to other studies investigating lysianassoid diversity in shallow high Antarctic waters, mostly using baited traps, the number of species encountered here is relatively high. Reports on amphipod trap deployments from the Scotia Sea (Burdwood Banks and near South Georgia), King George and Elephant Islands as well as the Antarctic Peninsula region (Larsen B and C areas), no deeper than $500 \mathrm{~m}$, showed a presence ranging from 1 to 6 lysianassoid species sampled and relative abundances varying from 173 to 20,000 individuals (Presler 1986; De Broyer et al. 2003; d'Udekem d'Acoz and Robert 2008; Havermans et al. 2013). However, caution is needed when comparing trap deployments, since the distance from which traps draw scavengers depends on a myriad of factors, e.g., the type, surface-to-volume ratio of bait, the direction, and velocity of the currents transporting the odour plume, species-specific swimming speeds, and daytime/night-time deployments (Sainte-Marie 1986, Sainte-Marie and Hargrave 1987). Similarly, the type of scavengers attracted by the bait depends on the type of the bait (reviewed in Havermans and Smetacek, submitted), and not all potentially attracted species may ultimately be feeding on the bait. Succession is influenced by arrival times and behavioural interactions related to competition, as well as predatory interactions, may also influence the final composition of species sampled on the bait. In coastal waters of King George Island, ten lysianassoid species were counted for Potter Cove (Seefeldt et al. 2017a); 5 of these 10 were reported for Admiralty Bay (Presler 1986). A total of 37 different morphospecies were counted in an account of all 22 trap deployments carried out in shallow waters by De Broyer 
et al. (2004) in stations across the Antarctic Peninsula region and Weddell Sea, compared to a total of 29 morphospecies recovered in the eastern Weddell Sea with the different types of gear used in this study. The number of species sampled seemed to be much higher in the case of deeper water trap deployments, where a maximum number of 12 lysianassoid species were found in a trap (2280 m depth, ANDEEP expedition, De Broyer et al. 2004). In single deployment of traps carried out in this study, also 12 morphospecies were recovered, which may indicate high species diversity in the region. However, trap deployments not only have many variables (e.g., time on the bottom, current velocities) that are difficult to account for when comparing their yields, especially in terms of abundances, but it was also shown that scavenging amphipods have a very patchy distribution with abundances varying enormously between traps deployed over a small area (e.g., the Larsen B area in the Peninsula region, d'Udekem d'Acoz and Robert 2008). Here, the dominant species was $O$. pinguides, whilst the proportion of $P$. plebs, the species usually dominating a trap sample, was quite low $(0.4 \%)$ compared to other trap samples deployed in the Scotia Sea as well as near an ice shelf in the Antarctic Peninsula area (Larsen B and C), where proportions ranged from 3 to 100\% (d'Udekem d'Acoz and Robert 2008; Havermans et al. 2013). Further trap deployments are needed to confirm whether particular species dominate specific regions and depths or whether these can be linked to available food and feeding preferences. P. plebs, $P$. rossi, and $P$. coatsi seem to be frequently recovered in very high numbers in trap deployments in the Scotia Sea and Peninsula region, Cheirimedon femoratus in the inner part of a glacial cove of King George Island (Seefeldt et al. 2017a), and W. obesa and A. nodimanus were the two dominant species in deployments in the East Antarctic sector (Arnaud 1974; Havermans, pers. obs.).

In none of the cases where several specimens per morphospecies, originating from distinct sampling localities, were sequenced, did we find a clear geographic or bathymetric segregation. Often, the distinct lineages observed within a morphospecies were found to occur in sympatry. Moreover, in many cases, a genetic homogeneity within a species was observed throughout the Filchner area and even between distinct basins. This was the case for P. plebs, for specimens sampled in the Scotia and Weddell seas and for $U$. murrayi morphospecies B, between specimens from the Ross and Weddell seas. Even though fast-evolving markers such as microsatellites should be applied to evaluate the extent of gene flow realized between these populations, it is clear from these and previous results that closely related lysianassoid species are characterized by a wide, but overlapping geographic and bathymetric ranges and allopatric sister species are rarely observed. This may still be a relic from the isolation of populations in glacial refugia, and subsequent diversification, as often hypothesized for Antarctic benthos (reviewed in Allcock and Strugnell 2012; Fraser et al. 2012). However, it may also indicate that selective forces other than vicariance, or physical barriers hampering dispersal, have been at play and that diversifications may likely have been caused by selective forces linked to the competition for food or predation pressure (discussed in Havermans and Smetacek, submitted).

\section{Hypotheses on feeding habits of the scavenging guild in the Filchner area and elsewhere}

In the absence of direct observations on natural feeding habits of scavenging animals, most of the information on their ecology and biogeography has been gathered from baited trap deployments (reviewed in Bailey et al. 2007). Lysianassoid amphipods are predominantly but not by default scavengers, but a few species are deposit-feeders or ectoparasites (Lowry and Stoddart 1983). Most lysianassoid genera and species identified in this study are known to be at least facultative scavengers (Dauby et al. 2001a, b; Nyssen et al. 2002). However, in the genus Lepidepecreella, some species are supposed to be obligate ectoparasites on sea urchin species whilst others are known to feed on moribund, damaged echinoderms (Schiaparelli et al. 2015). Although virtually nothing is known about members of the genus Lepidepecreum, including the here recorded $L$. urometacarinatum, neither associations with other invertebrates, nor occurrences in baited traps have been reported (Lowry and Stoddart 2002), so they are generally not considered to be parasitic or carrion-feeding.

Scavengers may feed on smaller and larger carcasses ranging from dead zooplankton bodies to those of fish, squid, and marine mammals (then referred to as carrionfeeders) but also plant material such as macrophytes or wood falls (reviewed in Havermans and Smetacek, submitted). The species-rich scavenging amphipod assemblage discovered in the Filchner area may be supported by a high diversity and abundance of resources in the region. Potential food falls for carrion-feeding amphipods and other scavenging organisms are manifold. The Filchner area, with its supercooled ice shelf waters, represents a key area for the distribution of both adult and larval Antarctic silverfish, Pleuragramma antarcticum, for which it is a nursery and retention area (e.g., Hubold 1984). Vertical feeding migrations of adult Pleuragramma (Knust et al. 2012) could result in large numbers of adults dying in proximity of the seafloor and a rain of dead larval individuals could occur in retention areas, sinking to the seafloor and supporting the scavenger community. Besides Pleuragramma, the Filchner Outflow System harbours many other bentho-pelagic and demersal fish (Ekau and Hubold 1985) such as the Jonah's icefish, Neopagetopsis ionah Nybelin, 1947, as well as the spiny 
icefish, Chaenodraco wilsoni Regan, 1914. The Filchner area was found to be an important region for these species as nursery grounds where they build nests or attach eggs to stones, respectively (Ambroso et al. 2014). Moreover, many females' carcasses were found in vicinity of the nests (Ambroso et al. 2014), suggesting that many may die after spawning, and their biomass would present a reliable seasonal food source as these species are known to spawn annually (Kock et al. 2008). Fish nests of these specimens with carcasses of dead fish were observed in high numbers on the eastern slope of the Filchner Trough, for example at the ROV stations 098 and St 277 (Ambroso et al. 2014). The trawl carried out at St 097 only contained dead and living Jonah's icefishes, and a single lysianassoid specimen of $P$. plebs, which may indicate the inefficiency of Agassiz trawls with their large mesh sizes for catching lysianassoids, rather than true low abundances. Furthermore, the rich benthic fauna that characterizes the Weddell Sea communities, including holothurians or other echinoderms can represent an important source of food for generalist or even specialist (e.g., Lepidepecreella) scavengers. Feeding on the abundant ichthyofauna such as silverfish, Weddell, and Crabeater seals are known to forage in the area (e.g., Plötz 1986; Plötz et al. 2001), and also southern elephant seals are hypothesized to do so (Daneri and Carlini 2002). Of these, some carcasses may end up in the water column and sink to the seafloor and, similar to whale falls (e.g., Smith and Baco 2003), are likely to sustain scavenger communities over months. Finally, iceberg scouring has also been shown to shape scavenger abundance and distribution patterns (Dunlop et al. 2014), and by causing a high faunal mortality of sessile invertebrates, dense aggregations of scavengers are often observed (e.g., Brown et al. 2004; Smale et al. 2007a, b). Finally, baited traps deployed at the same sites but in different seasons revealed that dominant scavenging taxa change according to the season (Smale et al. 2007b), adding a temporal component to scavenger richness which remains virtually unknown.

Local and regional scavenger distribution patterns, abundances and diversity may be influenced by both bottom-up factors such as benthic biomass and the occurrence of foraging or nursery grounds of pelagic fish and marine mammals, as well as top-down predation pressure of which the actors remain undocumented for this area. To which extent these factors shape the spatial and temporal distribution of scavengers needs to be further explored, but this knowledge is crucial to gain more information on their evolutionary ecology, regarding underlying causes of diversity, population sizes, turn-over rates, biogeography, and connectivity. Baited traps have been proven to be a useful tool, yielding the highest number of specimens:species ratio across all stations and gear, also shown in the previous studies (De Broyer et al. 2004; Seefeldt et al. 2017a). Nonetheless, due to the aforementioned unknown variables, the results of this method are difficult to quantify. Therefore, not only baited traps but a combination of gear should be used, such as fine-meshed dredges but also less destructive methods such as ROVs and AUVs. It is worthwhile to document the feeding habits of the different species in the scavenger guild by experimental and molecular or biomarker analyses, to assess their roles in carbon recycling of each component of the scavenger guild as well as their contribution in food-web models, which have hitherto been too often ignored or minimalized (e.g., Wilson and Wolkovich 2011; Moleón and Sánchez-Zapata 2015).

\section{Conclusions}

So far, a little importance has been accorded to research on scavenging marine fauna, despite the major importance of benthic and bentho-pelagic scavengers in recycling organic carbon reaching the ocean floor and in its upward transport back into the water column. Here, we presented an account on the lysianassoid amphipod fauna, representing a major component of the mobile scavenging guild, of eastern, western, and southernmost localities sampled in the Filchner area of the Weddell Sea. This area adjacent to the largest ice shelf by volume may represent a rather pristine condition, so far spared from major climate change effects, and can provide a baseline for faunal comparison with other areas, e.g., those under influence of glacier retreat (e.g., King George Island, Seefeldt et al. 2017a). Compared to this area and SO areas situated near ice shelves, such as those on the Antarctic Peninsula of which some parts only recently became exposed after ice shelf collapse events (d'Udekem d'Acoz and Robert 2008; Havermans et al. 2013), the Filchner Outflow System showed a high lysianassoid species richness. Our findings of several cryptic lineages, species new to science, and new records for the region underline the importance of integrative surveys combining molecular and morphological tools to fill in the knowledge gaps regarding species' distributions and diversity. To adequately monitor present and future biodiversity and the resilience of an ecosystem to change, in the context of an implementation of an MPA in this area sensitive to warming waters, it is crucial to determine the role, abundances and distribution of its different components. This is even more important knowing that not all scavenging amphipod species are flexible enough to colonise highly disturbed areas (e.g., after ice shelf collapse or glacial melting) and are also flexible in their food sources when food falls become rare (e.g., Seefeldt et al. 2017a, b). The development of standard protocols for baited trap deployments combined with video imagining of the benthic communities across areas with distinct environmental characteristics, e.g., across depth, pelagic/benthic biomass and temperature gradients, and in particular nursery or feeding grounds of higher trophic levels, may help to answer questions regarding the 
factors influencing species' distributions and shaping scavenger diversity patterns. As it has been shown that MPAs may significantly improve the resilience of communities (Mellin et al. 2016), an increasing knowledge of the invertebrate fauna of the region may help to establish adequate evaluation systems (Gallacher et al. 2016) and management plans (Brooks et al. 2016; Chown et al. 2017) to detect and monitor potential community shifts in times of rapid climate change (Brodersen and Seehausen 2014).

Acknowledgements This work was supported by the Deutsche Forschungsgemeinschaft (DFG, German Science Foundation) in the framework of the priority program "Antarctic Research with Comparative Investigations in Glaciated Areas of the Arctic" with the grant HA 7627/1-1 (C. Havermans), TO 171/9-1 and HE 3391/7-1 (C. Held and M.A. Seefeldt). Field work for this study was accomplished based on the Polarstern Grant No: AWI_PS82_03. We greatly acknowledge the Alfred Wegener Institute Helmholtz Centre for Polar and Marine Research, the Chief Scientist Dr. Rainer Knust, as well as the captain and crew of the R/V "Polarstern" expedition ANT-XXIX/9 (PS82) for their highly skillful support during the numerous sampling opportunities which we received on board. Particularly the "fish team" of PS82, Dr. Rainer Knust, Nils Koschnick, and colleagues are greatly acknowledged for the use of their lander system for the deployment of amphipod traps. Part of the molecular work carried out by C. Havermans in 2014 was supported by the vERSO project, funded by the Belgian Science Policy Office (BELSPO, contract no BR/132/A1/vERSO), to which this is manuscript contribution \#20. We are highly thankful to Dr. Claude De Broyer, Dr. Anna Jażdżewska, Dr. Saskia Brix as well as an anonymous reviewer for their valuable comments on the previous version of the manuscript.

Funding This work was supported by the Deutsche Forschungsgemeinschaft (DFG, German Science Foundation) in the framework of the priority program "Antarctic Research with Comparative Investigations in Glaciated Areas of the Arctic" with the grant HA 7627/1-1 (C. Havermans), TO 171/9-1 and HE 3391/7-1 (C. Held and M.A. Seefeldt).

\section{Compliance with ethical standards}

Conflict of interest The authors declare that they have no conflict of interest.

Ethical approval All applicable international, national, and/or institutional guidelines for the care and use of animals were followed.

\section{References}

Agardy T, Bridgewater P, Crosby MP, Day J, Dayton PK, Kenchington R, Laffoley D, McConney P, Murray PA, Parks JE, Peau L (2003) Dangerous targets? Unresolved issues and ideological clashes around marine protected areas. Aquat Conserv Mar Freshw Ecosyst 13:353-367. https://doi.org/10.1002/aqc.583

Allcock AL, Strugnell JM (2012) Southern Ocean diversity: new paradigms from molecular ecology. Trends Ecol Evol 27:520-528

Ambroso S, Casado de Amezua P, Beyer K, Biebow H, Böhmer A, Federwisch L, Gerdes D, Havermans C, Owsianowski N, Pineda S, Sands CJ, Zapata R, Held C, Eléaume M, Gili J-M, Richter C (2014) Benthos communities. In: Knust R, Schröder M (eds) The expedition PS92 of the Research Vessel Polarstern to the southern Weddell Sea in 2013/14. Ber Polarforsch Meeresforsch, vol 680. p 64-98

Andres HG (1986) Atylopsis procerus sp. n. und Cheirimedon solidus sp. n. aus der Weddell See sowie Anmerkungen zu Orchomenella pinguides Walker, 1903 (Crustacea: Amphipoda: Gammaridea). Mitt Hamb Zool Mus Inst 83:117-130

Arndt CE, Berge J, Brandt A (2005) Mouthpart-atlas of Arctic sympagic amphipods - trophic niche separation based on mouthpart morphology and feeding ecology. J Crust Biol 25:401-412

Arntz W, Brey T, Gallardo V (1994) Antarctic zoobenthos. Oceanogr Mar Biol Annu Rev 32:241-304

Auel H, Dürschslag J, Janssen D, Ksionzek K, Kohlbach D, Lange B, Vortkamp M, Flores H, Graeve M, Koch B (2014) Biological and biogeochemical processes in sea ice and the pelagic realm. In: Knust R, Schröder M (eds) The expedition PS92 of the Research Vessel Polarstern to the southern Weddell Sea in 2013/14. Ber Polarforsch Meeresforsch, vol 680. p 54-60

Bailey DM, King NJ, Priede IG (2007) Cameras and carcasses: historical and current methods for using artificial food falls to study deep-water animals. Mar Ecol Prog Ser 350:179-191

Barnard KH (1932) Amphipoda. Discov Rep 5:1-326

Bellard C, Bertelsmeier C, Leadley P, Thuiller W, Courchamp F (2012) Impacts of climate change on the future of biodiversity. Ecol Lett 15:365-377

Bornemann H, Oosthuizen WC, Bester MN (2014) Seal research at the Filchner Outflow System (SEAFOS). In: Knust R, Schröder M (eds) The expedition PS92 of the Research Vessel Polarstern to the southern Weddell Sea in 2013/14. Ber Polarforsch Meeresforsch, vol 680. p 115-135

Boulenger GA (1902) Pisces. Report on the collections of natural history made in the Antarctic regions during the voyage of the 'Southern Cross'. British Museum (Natural History), London, pp 174-189

Boysen-Ennen E (1987) On the distribution of meso- and macrozooplankton in the surface water of the Weddell Sea (Antarctica). Ber Polarforsch 35:1-126

Boysen-Ennen E, Piatkowski U (1988) Meso- and macrozooplankton communities in the Weddell Sea, Antarctica. Pol Biol 9:17-35

Britton JC, Morton B (1994) Marine carrion and scavengers. Oceanogr Mar Biol Annu Rev 32:369-434

Brodersen J, Seehausen O (2014) Why evolutionary biologists should get seriously involved in ecological monitoring and applied biodiversity assessment programs. Evol Appl 7:968-983. https:// doi.org/10.1111/eva.12215

Brooks CM, Crowder LB, Curran LM, Dunbar RB, Ainley DG, Dodds KJ, Gjerde KM, Sumaila UR (2016) Science-based management in decline in the Southern Ocean. Science 354:185-187

Brown KM, Fraser KPP, Barnes DKA, Peck LS (2004) Links between the structure of an Antarctic shallow-water community and ice-scour frequency. Oecologia 141:121-129. https://doi. org/10.1007/s00442-004-1648-6

CBD (2004) Convention on biological diversity decision, COP VII/5. http://www.cbd.int/doc/decisions/cop-07/cop-07-dec-05-en.doc

CBD (2010) Convention on biological diversity. Decision adopted by the conference of the parties to the convention on biological diversity at its 10th meeting, Nagoya, Japan 18-29 October. Decision X/2 The strategic plan for biodiversity 2011-2020 and the Aichi biodiversity targets

CCAMLR (2005) Commission for the conservation of Antarctic marine living resources-report of the 24th meeting of the commission, Hobart, Australia 24 October-4 November 2005. Report no. CCAMLR-XXIV

CCAMLR (2009) Commission for the conservation of Antarctic marine living resources-report of the 28th meeting of the commission Hobart, Australia 26 October-6 November 2009. Report no. CCAMLR-XXVIII 
CCAMLR (2011) Commission of the conservation of Antarctic marine living resources-report of the 30th meeting of the commission, Hobart, Australia 24 October-4 November 2011. Report no. CCAMLR-XXX

CCAMLR (2012) Commission for the conservation of Antarctic marine living resources-report of the 31 st meeting of the commission, Hobart, Australia 23 October-1 November 2012. Report no. CCAMLR-XXXI

CCAMLR (2016) Commission for the conservation of Antarctic marine living resources-report of the 35th meeting of the commission, Hobart, Australia 17-28 October 2016. Report no. CCAMLR-XXXV

Chenuil A, Saucède T, Hemery LG, Eléaume M, Féral JP, Améziane N, David B, Lecointre G, Havermans C (2018) Understanding processes at the origin of species flocks with a focus on the marine Antarctic fauna. Biol Rev 93:481-504. https://doi.org/10.1111/ brv. 12354

Chown SL, Brooks CM, Terauds A, Le Bohec C, van Klaveren-Imagliazzo C, Whittington JD, Butchart SHM, Coetzee BWT, Collen B, Convey P, Gaston KJ, Gilbert N, Gill M, Höft R, Johnston S, Kennicutt MC II, Kriessell HJ, Le Maho Y, Lynch HJ, Palomares M, Puig-Marcó R, Stoett P, McGeosh MA (2017) Antarctica and the strategic plan for biodiversity. PLoS Biol. https://doi. org/10.1371/journal.pbio.2001656

Clarke A (2008) Antarctic marine benthic diversity: patterns and processes. J Exp Mar Biol Ecol 366:48-55. https://doi.org/10.1016/j. jembe.2008.07.008

Collins RA, Boykin LM, Cruickshank RH, Armstrong KF (2012) Barcoding's next top model: an evaluation of nucleotide substitution models for specimen identification. Methods Ecol Evol 3:457-465

Costa F, DeWaard J, Boutillier J, Ratnasingham S, Dooh R, Hajibabaei M, Hebert P (2007) Biological identifications through DNA barcodes: the case of the Crustacea. Can J Fish Aquat Sci 64:272-295

Costa F, Henzler C, Lunt D, Whiteley N, Rock J (2009) Probing marine Gammarus (Amphipoda) taxonomy with DNA barcodes. Syst Biodivers 7:365-379

d'Udekem d'Acoz C, Robert H (2008) Systematic and ecological diversity of amphipods. In: Gutt J (ed) The expedition ANTARKTISXXIII/8 of the research vessel "Polarstern" in 2006/2007. Ber Polarforsch Meeresforsch 569:48-56

d'Udekem d'Acoz C, Havermans C (2012) Two new Pseudorchomene species from the Southern Ocean, with phylogenetic remarks on the genus and related species (Crustacea: Amphipoda: Lysianassoidea: Lysianassidae: Tryphosinae). Zootaxa 3310:1-50

Daneri G, Carlini A (2002) Fish prey of southern elephant seals, Mirounga leonina, at King George Island. Pol Biol 25:739-743

Darelius E, Makinson K, Daae K, Fer I, Holland PR, Nicholls KW (2014) Hydrography and circulation in the Filchner depression, Weddell Sea, Antarctica. J Geophys Res Oceans 119:5797-5814

Dauby P, Scailteur Y, Chapelle G, De Broyer C (2001a) Potential impact of the main benthic amphipods on the eastern Weddell Sea shelf ecosystem (Antarctica). Pol Biol 24:657-662

Dauby P, Scailteur Y, De Broyer C (2001b) Trophic diversity within the eastern Weddell Sea amphipod community. Hydrobiologia 443:69-86

De Broyer C (1975) Révision du genre Adeliella (Amphipoda, Gammaridea, Lysianassidae) et description d'une nouvelle espèce antarctique. Crustaceana 28:73-85

De Broyer C (1985a) Amphipodes lysianassö̈des nécrophages des îles Kerguelen (Crustacea): 1. Orchomenella guillei n.sp. Bull Mus Natl Hist Nat Paris 36:205-217

De Broyer C (1985b) Notes sur les Orchomene de l'Océan Austral. 3. Révision d'Orchomenella acanthura (Schellenberg) (Crustacea Amphipoda: Lysianassoidea). J Nat Hist 19:729-738
De Broyer C, Lörz A-N, Nyssen F, Rauschert M, Cariceo Y, Rios C (2003) Biodiversity, biogeography, phylogeny and trophodynamics of amphipod and isopod crustaceans. In: Arntz WE and Brey T (eds) Expedition ANTARKTIS XIX/5 (LAMPOS) of RV "Polarstern" in 2002. Ber Polarforsch Meeresforsch 462:34-44

De Broyer C, Nyssen F, Dauby P (2004) The crustacean scavenger guild in Antarctic shelf, bathyal and abyssal communities. Deep Sea Res Part II Top Stud Oceanogr 51:1733-1752

De Broyer C, Lowry JK, Jażdżewski K, Robert H (2007) Catalogue of the Gammaridean and Corophiidean Amphipoda (Crustacea) of the Southern Ocean with distribution and ecological data. In: De Broyer C (ed) Census of Antarctic marine life: synopsis of the Amphipoda of the Southern Ocean. Bull Inst R Sci Nat Belg 77:1-325

De Broyer C, Koubbi P, Griffiths HJ, Raymond B, d'Udekem d'Acoz C, Van de Putte AP, Danis B, David B, Grant S, Gutt J, Held C, Hosie G, Huettmann F, Post A, Ropert-Coudert Y (eds) (2014) Biogeographic Atlas of the Southern Ocean. Scientific Committee on Antarctic Research, Cambridge, UK, pp 328-362

Duffy JE, Godwin CM, Cardinale BJ (2017) Biodiversity effects in the wild are common and as strong as key drivers of productivity. Nature. https://doi.org/10.1038/nature23886

Dunlop KM, Barnes DKA, Bailey DM (2014) Variation of scavenger richness and abundance between sites of high and low iceberg scour frequency in Ryder Bay, west Antarctic Peninsula. Polar Biol 37:1741-1754

Ekau W, Hubold G (1985) Fish and fish larvae Hempel G die expedition ANTARKTIS III mit FS "Polarstern"1984/85. Ber Polarforsch 25:121-129

Fišer Z, Altermatt F, Zakšek V, Knapič T, Fišer C (2015) Morphologically cryptic amphipod species are ecological clones at regional but not at local scale: a case study of four Niphargus species. PLoS ONE. https://doi.org/10.1371/journ al.pone. 0134384

Foldvik A, Gammelsrød T, Østerhus S, Fahrbach E, Rohardt G, Schröder M, Nicholls KW, Padman W, Woodgate RA (2004) Ice shelf water overflow and bottom water formation in the southern Weddell Sea. J Geophys Res. https://doi.org/10.1029/2003J C002008

Folmer O, Hoeh W, Black M, Vrijenhoek R (1994) Conserved primers for PCR amplification of mitochondrial DNA from different invertebrate phyla. Mol Mar Biol Biotechnol 3:294-299

Fox AJ, Cooper APR (1994) Measured properties of the Antarctic ice sheet derived from the SCAR Antarctic digital database. Polar Rec 30:201-206

Fraser CI, Nikula R, Ruzzante DE, Waters JM (2012) Poleward bound: biological impacts of Southern Hemisphere glaciation. Trends Ecol Evol 27:462-471

Gallacher J, Simmonds N, Fellowes H, Brown N, Gill N, Clark W, Biggs C, Rodwell L (2016) Evaluating the success of a marine protected area: a systematic review approach. J Environ Manag $183: 280-293$

Griffiths HJ (2010) Antarctic marine biodiversity_what do we know about the distribution of life in the southern ocean? PLoS ONE. https://doi.org/10.1371/journal.pone.0011683

Grosfeld K, Gerdes R (1998) Circulation beneath the Filchner ice shelf, Antarctica, and its sensitivity to changes in the oceanic environment: a case-study. Ann Glaciol 27:99-104

Grosfeld K, Schröder M, Fahrbach E, Gerdes R, Mackensen A (2001) How iceberg calving and grounding change the circulation and hydrography in the Filchner ice shelf-ocean system. J Geophys Res 106:9039-9055

Gutt J, Griffiths HJ, Jones CD (2013) Circumpolar overview and spatial heterogeneity of Antarctic macrobenthic communities. Mar Biodivers 43:481-487 
Haid V, Timmermann R (2013) Simulated heat flux and sea ice production at coastal polynyas in the southwestern Weddell Sea. J Geophys Res Oceans 118:2640-2652

Harley CDG (2011) Climate change, keystone predation, and biodiversity loss. Science 334:1124-1127

Havermans C (2012) DNA barcoding, phylogeography and phylogeny of the Lysianassoidea (Crustacea: Amphiopda) from the Southern Ocean and the Worlds Deep Seas. Dissertation, Université Catholique de Louvain

Havermans C (2014) Chapter 10.6. Phylogeographic patterns of the Lysianassoidea (Crustacea: Peracarida: Amphipoda). In: De Broyer C, Koubbi P, Griffiths HJ, Raymond B, d'Acoz CUD et al (eds.) Biogeographic atlas of the Southern Ocean. Scientific Committee on Antarctic Research, Cambridge, p 441-447

Havermans C, Nagy Z, Sonet G, De Broyer C, Martin P (2010) Incongruence between molecular phylogeny and morphological classification in amphipod crustaceans: a case study of Antarctic lysianassoids. Mol Phylogenet Evol 55:202-209

Havermans C, Nagy Z, Sonet G, De Broyer C, Martin P (2011) DNA barcoding reveals new insights into the diversity of Antarctic species of Orchomene sensu lato (Crustacea: Amphipoda: Lysianassoidea). Deep Sea Res Part II Top Stud Oceanogr 58:230-241

Havermans C, Robert H, d'Acoz CDU (2013) Biodiversity and phylogeographic patterns of amphipod crustaceans in Antarctic seas. In: Knust R, Gerdes D, Mintenbeck K (eds) The expedition of the research vessel "Polarstern" to the Antarctic in 2011 (ANTXXVII/3) (CAMBIO). Ber Polarforsch Meeresforsch 644:35-40

Hebert PD, Ratnasingham S, de Waard JR (2003) Barcoding animal life: cytochrome $\mathrm{c}$ oxidase subunit 1 divergences among closely related species. Proc R Soc Lond B Biol Sci 270:S96-S99

Hellmer HH, Kauker F, Timmermann R, Hattermann T (2017) The fate of the Southern Weddell Sea continental shelf in a warming Climate. J Clim 30:4337-4350. https://doi.org/10.1175/ JCLI-D-16-0420.1

Horton T, Lowry J, De Broyer C, Bellan-Santini D, Coleman CO, Daneliya M, Dauvin J-C, Fišer C, Gasca R, Grabowski M, Guerra-García JM, Hendrycks, E, Holsinger J, Hughes L, Jaume D, Jażdżewski K, Just J, Kamaltynov RM, Kim YH, King R, Krapp-Schickel T, LeCroy S, Lörz AN, Senna AR, Serejo C, Sket B, Tandberg AH, Thomas J, Thurston M, Vader W, Väinölä R, Vonk R, White K, Zeidler W (2017) World Amphipoda Database. http://www.marinespecies.org/amphipoda. Accessed 14 Sept 2017

Hubold G (1984) Spatial distribution of Pleuragramma antarcticum (Pisces: Nototheniidae) near the Filchner- and Larsen ice shelves (Weddell Sea/Antarctica). Pol Biol 3:231-236

Hurley D (1963) Amphipoda of the family Lysianassidae from the west coast of North and Central America. University of Southern California Press

Hurley D (1965a) A common but hitherto undescribed species of Orchomenella (Crustacea: Amphipoda family Lysianassidae) from Ross Sea. Trans Roy Soc NZ Zool 6:107

Hurley D (1965b) A re-description of some AO Walker types of the southern cross Lysianassidae (Crustacea Amphipoda) from Ross Sea. Trans Roy Soc NZ Zool 6:155

Jackson JBC, Kirby MX, Berger WH, Bjornda KA, Botsford LW, Bourque BJ, Bradbury RH, Cooke R, Erlandson J, Estes JA, Hughes TP, Kidwel S, Lange CB, Lenihan HS, Pandolfi JM, Peterson CH, Steneck RS, Tegner MJ, Warner RR (2001) Historical overfishing and the recent collapse of coastal ecosystems. Science 293:629-637. https://doi.org/10.1126/science.1059199

Jażdżewska AM, Corbari L, Driskell A, Frutos I, Havermans C, Hendrycks E, Hughes L, Lörz A-N, Stransky B, Tandberg AHS, Vader W, Brix S (2018) A genetic fingerprint of Amphipoda from Icelandic waters - thebaseline for further biodiversity and biogeography studies. In: Brix S, Lörz A-N, Stransky
B, Svavarsson J(eds) Amphipoda from the IceAGE-project (Icelandic marine Animals: Genetics and Ecology). ZooKeys 731:55-73. https://doi.org/10.3897/zookeys.731.19931

Kilgallen N, Lowry J (2014) The Tryphosa group (Crustacea: Amphipoda: Lysianassoidea: Lysianassidae: Tryphosinae). Zootaxa 3768:501-545

Kilgallen N, Lowry J (2015a) The genus Hippomedon in Australian waters (Crustacea, Amphipoda, Lysianassidae, Tryphosinae). Zootaxa 3926:377-395

Kilgallen N, Lowry J (2015b) The tryphosine genus Cheirimedon in Australian waters (Crustacea, Amphipoda, Lysianassidae, Tryphosinae). Zootaxa 4014:1-68

King NJ, Bailey DM, Priede IG (2007) Role of scavengers in marine ecosystems. Mar Ecol Prog Ser 350:175-178

Knust R, Schröder M (2014) The expedition PS82 of the research vessel polarstern to the southern Weddell Sea in 2013/14. Ber Polarforsch Meeresforsch 680:1-155. https://doi.org/10.2312/ BzPM_0680_2014

Knust R, Gerdes D, Mintenbeck K (2012) The expedition of the Research Vessel Polarstern to the Antarctic in 2011 (ANTXXVII/3) (CAMBIO). Ber Polarforsch Meeresforsch 644: 1-202. hdl: 10013/epic.39114

Kock KH, Pshenichnov L, Jones CD, Gröger J, Riehl R (2008) The biology of the spiny icefish Chaenodraco wilsoni Regan, 1914. Polar Biol 31:381-393. https://doi.org/10.1007/s0030 0-007-0366-Z

Lowry J, Kilgallen N (2014a) A generic review of the lysianassoid family Uristidae and descriptions of new taxa from Australian waters (Crustacea, Amphipoda, Uristidae). Zootaxa 3867:1-92

Lowry J, Kilgallen N (2014b) A revision of the lysianassid genus Waldeckia with the description of four new species (Crustacea, Amphipoda, Lysianassidae, Waldeckiinae subfam. nov.). Zootaxa 3784:301-345

Lowry J, Kilgallen N (2015a) Debroyerella gen. nov. and Ulladulla gen. nov., two new lysianassoid genera (Crustacea, Amphipoda, Lysianassoidea). Zootaxa 3920:153-162

Lowry J, Kilgallen N (2015b) A new species of Waldeckia from the Austral Isles, Society Islands (Amphipoda, Lysianassoidea, Lysianassidae, Waldeckiinae). Zootaxa 3995:78-83

Lowry J, Stoddart H (1983) The shallow-water gammaridean Amphipoda of the subantarctic islands of New Zealand and Australia: Lysianassoidea. J Roy Soc NZ 13:279-394

Lowry J, Stoddart H (1993) The Onisimus problem (Amphipoda, Lysianassoidea, Uristidae). Zool Scr 22:167-181

Lowry J, Stoddart H (1995) The Amphipoda (Crustacea) of Madang Lagoon: Lysianassidae, Opisidae, Uristidae, Wandinidae and Stegocephalidae. Rec Aust Mus 22:97-174

Lowry J, Stoddart H (1997) Amphipoda Crustacea IV. Families Aristiidae, Cyphocarididae, Endevouridae, Lysianassidae, Scopelocheiridae, Uristidae. Mem Hourglass Cruises 10:1-130

Lowry J, Stoddart H (2002) The lysianassoid amphipod genera Lepidepecreoides and Lepidepecreum in southern waters (Crustacea: Lysianassidae: Tryphosinae). Rec Aust Mus 54:335-364

Lowry J, Stoddart H (2011) The tryphosine genera Photosella gen. nov. and Tryphosella Bonnier, 1893 (Crustacea: Amphipoda: Lysianassoidea: Lysianassidae: Tryphosinae) in Australian waters. Zootaxa 2956:1-76

Mellin C, Aaron MacNeil M, Cheal AJ, Emslie MJ, Julian Caley M (2016) Marine protected areas increase resilience among coral reef communities. Ecol Lett 19:629-637

Moleón M, Sánchez-Zapata JA (2015) The living dead: time to integrate scavenging into ecological teaching. BioSci 65:1003-1010

Mori A (2016) Resilience in the studies of biodiversity-ecosystem functioning. Trends Ecol Evol 31:87-89 
Mori A, Furukawa T, Sasaki T (2013) Response diversity determines the resilience of ecosystems to environmental change. Biol Rev 88:349-364

Nimmo DG, Mac Nally R, Cunningham SC, Haslem A, Bennett AF (2015) Vive la résistance: reviving resistance for 21 st century conservation. Trends Ecol Evol 30:516-523

Nybelin O (1947) Antarctic fishes. Sci result Norweg Antarc Exped 1927-28 26:1-76

Nyssen F, Brey T, Lepoint G, Bouquegneau J-M, De Broyer C, Dauby P (2002) A stable isotope approach to the eastern Weddell Sea trophic web: focus on benthic amphipods. Pol Biol 25:280-287

Plötz J (1986) Summer diet of Weddell seals (Leptonychotes weddelli) in the Eastern and Southern Weddell Sea, Antarctica. Pol Biol 6:97-102

Plötz J, Bornemannn H, Knust R, Schröder A, Bester M (2001) Foraging behaviour of Weddell seals, and its ecological implications. Pol Biol 24:901-909

Presler P (1986) Necrophagous invertebrates of the admiralty Bay of King George Island (South Shetland Islands, Antarctica). Pol Polar Res 7:25-61

Puillandre N, Lambert A, Brouillet S, Achaz G (2012) ABGD, automatic barcode gap discovery for primary species delimitation. Mol Ecol 21:1864-1877

Radulovici AE, Sainte-Marie B, Dufresne F (2009) DNA barcoding of marine crustaceans from the estuary and Gulf of St Lawrence: a regional-scale approach. Mol Ecol Res 9:181-187

Ratnasingham S, Hebert P (2007) BOLD: the barcode of life data system (www. barcodinglife. org). Mol Ecol Notes 7:355-364

Regan CT (1914) Diagnosis of new marine fishes collected by the British Antarctic ("Terra Nova") Expedition. Ann Mag nat Hist 13:11-17

Sainte-Marie B (1986) Effect of bait size and sampling time on the attraction of the lysianassid amphipods Anonyx sarsi Steele \& Brunel and Orchomenella pinguis (Boeck). J Exp Mar Biol Ecol 99:63-77. https://doi.org/10.1016/0022-0981(86)90021-3

Sainte-Marie B, Hargrave BT (1987) Estimation of scavenger abundance and distance of attraction to bait. Mar Biol 94:431-443

Scheffer M, Carpenter SR (2003) Catastrophic regime shifts in ecosystems: linking theory to observation. Trends Ecol Evol 18:648-656

Schellenberg A (1926) Die gammariden der deutschen sudpolar-expedition 1901-1903. Deutsche Südpolar-Expedition 1901-1903(18):235-414

Schellenberg A (1931) Gammariden und Caprelliden des Magellangebietes, Sudgeorgiens und der Westantarktis. Furth Zool Results Swed Antarct Exped 1901-1903(2):1-290

Schiaparelli S, Alvaro MC, Kilgallen N, Scinto A, Lörz A-N (2015) Host-shift speciation in Antarctic symbiotic invertebrates: further evidence from the new amphipod species Lepidepecreella debroyeri from the Ross Sea? Hydrobiologia 761:143-159

Schlitzer R (2015) Ocean data view. http://odv.awi.de

Seefeldt MA (2012) Morphological analyses to clarify the systematics of the Uristes murrayi (Walker, 1903) species complex in the Southern Ocean (Crustacea, Amphipoda, Lysianassoidea). Master thesis, Ruhr-University Bochum

Seefeldt MA, Weigand AM, Havermans C, Moreira E, Held C (2017a) Fishing for scavengers: an integrated study to amphipod (Crustacea: Lysianassoidea) diversity of Potter Cove, South Shetland Islands, Antarctica. Mar Biodiv. https://doi.org/10.1007/s1252 6-017-0737-9
Seefeldt MA, Campana GL, Deregibus D, Quartino ML, Abele D, Held C (2017b) Feeding strategies in Antarctic scavenging amphipods and their implications for colonisation success in times of retreating glaciers. Front Zool 14:59. https://doi.org/10.1186/ s12983-017-0248-3

Slattery PN, Oliver JS (1986) Scavenging and other feeding habits of Lysianassid amphipods (Orchomene spp.) from McMurdo sound, Antarctica. Polar Biol 6:171-177

Smale DA, Barnes DKA, Fraser KPP (2007a) The influence of depth, site exposure and season on the intensity of iceberg scouring in nearshore Antarctic waters. Polar Biol 30:769-779. https://doi. org/10.1007/s00300-006-0236-0

Smale DA, Barnes DKA, Fraser KPP (2007b) The influence of depth, site exposure and season on the intensity of iceberg scouring in nearshore Antarctic waters. Polar Biol 30:769-779. https://doi. org/10.1007/s00300-006-0236-0

Smith CR, Baco AR (2003) Ecology of whale falls at the deep-sea floor. Oceanogr Mar Biol Ann Rev 41:311-354

Stebbing TRR (1888) Report on the Amphipoda collected by H.M.S challenger during the years 1873-1876. Report on the scientific results of the Voyage of H.M.S. challenger during the years 1873-76. Zoology 29:1-1737

Tamura K, Stecher G, Peterson D, Filipski A, Kumar S (2013) MEGA6: molecular evolutionary genetics analysis version 6.0. Mol Biol Evol 30:2725-2729

Teschke K, Beaver D, Bester MN, Bombosch A, Bornemann H, Brandt A, Brtnik P, De Broyer C, Burkhardt E, Danis B, Dieckmann G, Douglass L, Flores H, Gerdes D, Griffiths HJ, Gutt J, Hain S, Hauck J, Hellmer H, Herata H, Hoppema M, Isla E, Jerosch, Kaiser S, Koubbi P, Kock K-H, Krause R, Kuhn G, Lemke P, Liebschner A, Linse K, Miller H, Mintenbeck K, Nixfdorf U, Pehlke H, Post A, Schröder M, Shust KV, Schwegmann S, Siegel V, Strass V, Thomisch K, Timmermann R, Trathan PN, van de Putte A, van Franeker J, van Opzeeland IC, von Nordheim H, Brey T (2016) Scientific background document in support of the development of a CCAMLR MPA in the Weddell Sea (Antarctica) - version 2016-part A: general context of the establishment of MPAs and background information on the Weddell Sea MPA planning area. CCAMLR. p 1-112

Thompson JD, Higgings DG, Gibson TJ (1994) Clustal W: improving the sensitivity of progressive multiple sequence alignment through sequence weighting, position-specific gap penalties and weight matrix choice. Nucl Acid Res 22:4673-4680. https://doi. org/10.1093/nar/22.22.4673

UNSDG (2015) United Nations sustainable development goals, GA 70/1. http://www.un.org/ga/search/view_doc.asp?symbol=A/ RES/70/1\&Lang $=\mathrm{E}$

Walker AO (1903) Amphipoda of the 'Southern Cross' Antarctic expedition. Zool J Linn Soc 29:38-64

Wilson EE, Wolkovich EM (2011) Scavenging: how carnivores and carrion structure communities. Trends Ecol Evol 26:135

Worm B, Sandow M, Oschlies A, Lotze H, Myers RA (2005) Global patterns of predator diversity in the open oceans. Science 309:1365-1369. https://doi.org/10.1126/science.1113399

Worm B, Barbier EB, Beaumont N, Duffy JE, Folke C, Halpern BS, Jackson JBC, Lotze HK, Micheli F, Palumbi S, Sala E, Selkoe KA, Stachowicz JJ, Watson R (2006) Impacts of biodiversity loss on ocean ecosystem services. Science 314:787-790 